Arqueología y Sociedad,

$N^{\circ} 16,2005$

\title{
Pacopampa. Un centro formativo en la sierra nor-peruana*
}

\author{
Hermilio Rosas La Noire \\ Ruth Shady Solís
}

Esta investigación fue realizada con los restos arqueológicos obtenidos de los trabajos de campo que efectuáramos en el sitio de Pacopampa, Chota, de agosto a diciembre de 1967; fue entregada a la Universidad de San Marcos en diciembre de 1969 para su publicación, pero por circunstancias varias se postergó hasta el presente.

Con motivo del XXXIX Congreso Internacional de Americanistas, presentamos un informe abreviado, el mismo que aparecerá en el próximo número de la Revista del Museo de Arqueología de la Universidad.

Nuestro propósito fue dar a conocer la naturaleza de los materiales y trazar un esquema tentativo del desarrollo cultural durante el período Formativo en Pacopampa. Los resultados son preliminares dada nuestra corta permanencia allí y están sujetos a correcciones, conforme se intensifiquen los trabajos de campo y se complete la clasificación de los objetos recobrados con sus respectivos cuadros.

Deseamos expresar nuestro reconocimiento al Dr. Pablo Macera, director del Seminario de Historia Rural Andina de la Universidad de San Marcos, quien promovió nuestra investigación, así como al Dr. Jorge C. Muelle, director del Museo Nacional de Antropología y Arqueología.

Estamos igualmente agradecidos al personal del Museo Nacional de Antropología y Arqueología, en especial al Sr. Julio Espejo Núñez, por la colaboración espontánea prestada en la preparación de los materiales. Debemos resaltar la ayuda recibida del Sr. Emilio Choy, y mencionar a la familia Tapia-Huanambal por su decidido apoyo durante nuestra estada en Pacopampa.

* Publicado originalmente por el Seminario de Historia Rural Andina, Lima, 1970. 


\section{Pacopampa}

Pacopampa es el nombre actual de un pueblo anexo al distrito de Querocoto, provincia de Chota, Cajamarca. Está ubicado en la vertiente oriental de la cordillera occidental de los Andes, en los $79^{\circ} 1^{\prime}$ de longitud este y $6^{\circ} 20^{\prime}$ de latitud sur, entre el distrito de Huambos al sur y poblaciones de la provincia de Cutervo al norte y este (Fig. 1).

La topografía en gran parte es abrupta y accidentada, drenada al este por el río Chotano que se desarrolla alimentado por ríos y riachuelos procedentes de áreas altas húmedas y discurre por los pliegues de rocas metamórficas y sedimentarias hasta su confluencia con el Huancabamba para dar origen al río Chamaya, cercano al pueblo de Pucara, y tributar posteriormente sus aguas al Marañón.

El lecho del río, que transportaba abundante agua antes de la construcción de la gran represa de Tinajones, ocupaba casi todo el fondo de la quebrada, dejando angostos espacios adyacentes; los terrenos de ladera, que son la mayoría, con declive marcado, están muy elevados sobre el nivel actual del río, ofreciendo una gradiente variada desde los ligeramente inclinados hasta las pendientes casi verticales alcanzando elevaciones de 3,600 metros en las "Jalcas".

La región puede ser descrita en tres grandes zonas ecológicas, distinguidas ya por los naturales y diferenciadas climática y geográficamente: "Jalca" (o Pradera Montano. Tosi, 1960, p.109), entre los 2,800 y 3,650 metros, comprende las tierras "altas", frías y húmedas, favorables para los pastos y crianza de ganado; una zona intermedia o "Quichua" (Bosque húmedo montano bajo. ob. cit. p.162), desde los 2,300 metros de clima templado, dedicada a la agricultura de rekacha, maíz, frijol, calabaza, yacón, papa, etc.; y la cálida húmeda del "Temple" (sabana o bosque muy seco tropical. ob. cit. p.88), por debajo de los 2,300 metros, con sembríos de plantas tropicales, cacao, café, caña de azúcar, yuca, camote, cítricos, etc.

El sitio arqueológico se encuentra a un kilómetro al oeste del actual pueblo de Pacopampa, entre Querocoto y Querocotillo, distritos norteños de las provincias de Chota y Cutervo. Según la diferenciación ecológica pertenece a la zona "quichua", tiene 2,410 metros de altura y le caracteriza un clima suave con temperaturas medias entre 16 y $18^{\circ} \mathrm{C}$.

Su ubicación central, entre zonas de diversa ecología, le permite el aprovechamiento de variados recursos naturales facilitado por la corta distancia que existe de una zona a otra, lo que habría favorecido el desarrollo de un centro ceremonial, con viviendas dispersas en pequeñas unidades rurales.

Los suelos en algunos sectores son litosólicos y pedregosos en su mayor parte de secano. La población actual, dedicada a la actividad agropecuaria, ha tenido necesidad de construir un canal y conducir agua desde la "Rimana", sitio alejado en la Jalca, hasta los terrenos de cultivo; sin embargo, la cantidad es insuficiente, quedando numerosas tierras a expensas de la precipitación pluvial que en años de sequía, muy frecuentes, afecta seriamente la economía de la región. No obstante, es interesante anotar la existencia de agua de subsuelo a pocos metros de profundidad, destinada generalmente para uso doméstico. Probablemente sea otro de los motivos para que los nativos pobladores encontraran propicio el lugar. Actualmente la caza en los bosques es esporádica y casual. En ellos viven en forma silvestre, cuyes, venados y osos. Es posible que la caza fuese mayor en el pasado y que el hombre dedicase más tiempo a esta actividad, como lo revela la abundante presencia de estas especies en las excavaciones. La cacería indiscriminada del hombre actual y la tala de los bosques para su incorporación a la agricultura, ha reducido su hábitat.

\section{Antecedentes históricos}

Rafael Larco Hoyle, director del Museo de Chiclín, Trujillo, a base de los informes y fotografías que le enviara el Monseñor Pérez Silva, Administrador Apostólico de la Diócesis de Caja- 


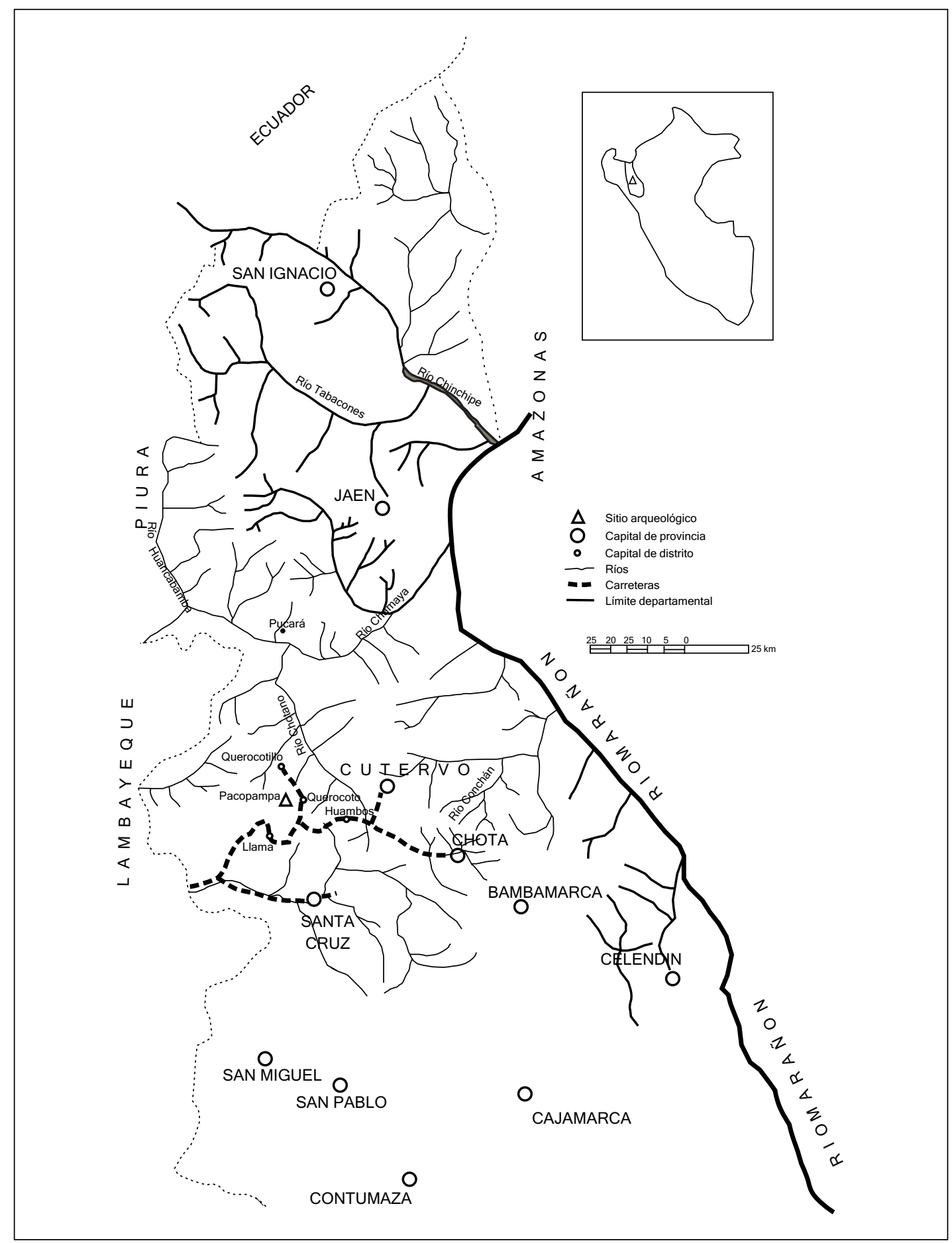

Figura 1. Ubicación geográfica del sitio arqueológico de Pacopampa en el departamento de Cajamarca. 
marca, organizó una expedición a las ruinas de Pacopampa. Durante su permanencia, de seis días, formó una valiosa colección de cerámica, objetos de piedra y hueso, parte de la cual dio a publicidad en diarios de Lima y Trujillo el año 1939. ${ }^{1}$ A partir de esta fecha, los mismos objetos han sido presentados por otros investigadores señalando procedencia distinta. Así, Rebeca Carrión Cachot (1948), ilustra dos morteros de piedra tallados como originarios del valle de Chicama (p.126, figs. a, b) y una figura de felino, también tallada en piedra como mortero (p. 125, fig. 12) . En realidad, las dos primeras piezas fueron adquiridas por Larco de Críspulo Tapia, natural de Pacopampa, quien en forma casual durante las labores de chacra descubriera una tumba rectangular a un kilómetro y medio al este del templo y que tenía por ofrenda los morteros, entre otros objetos; mientras que el felino fue hallado junto con otro de mayores dimensiones por Daniel Farro, propietario de los terrenos que ocupa el templo y luego entregado a Larco. Son felinos casi de tamaño natural, uno más grueso que el otro, con el cuerpo exornado con puntos y círculos y no un mortero como reza en la obra de la doctora Rebeca Carrión. ${ }^{2}$

Encontramos similares confusiones en la ubicación geográfica de las ruinas. En la obra Chavín, cultura matriz de la civilización andina, de Julio C. Tello, Pacopampa es ubicado en las alturas del río Chancay (p.24), y más adelante (p.30), menciona como sitios de filiación Chavín, Huambos y Pacopampa, en la provincia de Cutervo (Tello, 1960). Estos errores han seguido, pues últimamente en la introducción a una antología (1970, p.19), Bonavía lo confunde con las ruinas que Wiener describe cerca de Handoval (actualmente Sandoval) en Áncash.

Después de 28 años de silencio (1939-1967), el sitio cobra nuevamente importancia arqueológica gracias a la visita hecha por el director del
"Seminario de Historia Rural Andina”, Dr. Pablo Macera, en 1966, quien a su regreso gestiona fondos en la Universidad Nacional Mayor de San Marcos, e invita al Museo Nacional de Antropología y Arqueología a participar en el proyecto, siendo favorecidos en la designación del Museo.

Después de elaborar un plan de trabajo, con pequeños fondos otorgados por la universidad, viajamos a Pacopampa e iniciamos la exploración y excavaciones. Los trabajos se efectuaron en dos etapas, agosto-setiembre y noviembrediciembre de 1967.

\section{Evidencias arqueológicas de superficie}

El pueblo de Pacopampa se encuentra estrechamente cerrado hacia el oeste por una gran elevación del terreno que culmina en dos montículos menores de formación natural denominados "La Capilla" y el "Mirador", cerros encantados según la versión de los pobladores; es de propiedad de la familia Tapia. Un kilómetro y medio al oeste de ellos, se destaca en el horizonte la silueta majestuosa de una estructura piramidal, compuesta por tres grandes plataformas escalonadas. Son conocidas por la gente de la región como las "Minas de San Pedro", desde hoy en el texto, "Templo de Pacopampa" (Fig. 3).

El templo, con frente hacia el Este, tiene una extensión aproximada de 600 por 200 metros y una altura de 35 metros sobre el nivel del piso de la primera plataforma (Fig. 2).

Antes de iniciar los trabajos de excavación se hizo una exploración y registro cuidadoso de todos los restos culturales de superficie, recorriendo con tal propósito el área total ocupada por el templo. Los objetos líticos que de algún modo formaron parte de unidades arquitectónicas son:

\section{Primera plataforma}

La mayor en dimensión, pero de relieve irregular, con frente a una amplia meseta en cuyo

1 La Crónica, 1 de octubre de 1939, pp. 16-18 y 26; La Nación, 3 y 4 de octubre de 1939, Trujillo.

2 Carrión Cachot, Rebeca. "La cultura Chavín: Dos nuevas colonias: Kuntur Wassi y Ancón". En: Revista del Museo Nacional de Antropología y Arqueología, vol. 2, N 1, pp. 99-172, Lima, 1948. 
centro se observa un gran montículo de apariencia artificial, lado este. Se encuentra dividida por una acequia moderna que hace su ingreso por el ángulo superior oeste y avanza hacia el centro de la plataforma, describiendo una curva, para luego desviar su curso en línea recta hacia el este y desembocar en la meseta. En el corte hecho por el agua se puede apreciar por sectores restos de muros que se orientan de norte a sur, pero en la mayor parte del recorrido se ve roca natural, evidenciando que en la construcción de la plataforma ha sido aprovechada una elevación natural.

Los restos de muros descubiertos por nosotros en el corte 5, ubicado en el ángulo superior del extremo sur de la primera plataforma, parecen indicar que las terrazas estaban divididas por grandes muros, hoy bajo tierra, y comunicadas por espaciosas graderías frontales y galerías subterráneas; una gran escalinata, ubicada al centro de la segunda plataforma, daba acceso a una sección superior, y el hallazgo de dos felinos al pie de la grada parece indicar que estaban adornadas o guardadas por felinos tallados en piedra fina, casi de tamaño natural. ${ }^{3}$

Pero la historia de los complejos arquitectónicos no datan de la misma época y esto se aprecia con toda claridad en el gran muro de 5 metros de altura que descubrimos en forma casual en el corte $1 \mathrm{~B}$, donde las diferencias de construcción son observadas sin ningún esfuerzo. El muro fue ubicado a 24 metros oeste de la escalinata mencionada. En esta plataforma (primera), la pieza de superficie más importante es una corniza de 3.50 metros de largo por $50 \mathrm{~cm}$ de ancho y $33 \mathrm{~cm}$ de espesor, con figuras de serpientes talladas en alto relieve en una de sus caras. Las cabezas de las serpientes se encuentran seriamente deterioradas. La piedra actualmente forma parte de una pared divisoria entre el camino de herradura Querocoto-Querocotillo y las ruinas. Igualmente registramos un fragmento de columna ubicado a 48 metros sur de la corniza, formando parte del mismo muro. Por el diámetro $(50 \mathrm{~cm})$ y la calidad de la piedra, parece ser parte de otra columna que se encuentra en la tercera plataforma. Otros restos corresponden a simples piedras de tamaño y forma variada, algunas delicadamente talladas.

\section{Segunda plataforma}

De forma rectangular, relieve uniforme en los 30 metros iniciales, lado este; después el terreno se eleva a 2.50 metros en toda su extensión, formando un corredor de unos 24 metros de ancho que comunica con una gradería central descubierta por nosotros: "La Portada de los Felinos". En este corredor se ubica la "Galería del Muerto" (llamado así por servir de sepultura temporal), explorada y limpiada por nosotros en los 84 metros de largo, donde se interrumpe.

Hacia el oeste la plataforma está limitada por un gran muro de 5 metros de alto, cubierto totalmente por relleno, que forma el segundo corredor pero de relieve irregular, con algunos metros de diferencia en relación al piso de la Portada de los Felinos. El desnivel es aún mayor a medida que se avanza hacia el muro B, que separa ésta de la tercera plataforma, igualmente descubierto y limpiado por nosotros. Tiene un largo actual de 118 metros y una altura promedio de 2.50 metros. Llama la atención la ausencia de escaleras que comuniquen ambas plataformas, teniendo en cuenta que la altura del muro debió ser mayor a los $2.50 \mathrm{~m}$, porque en un área no menor de 25 metros de ancho a lo largo del muro se encuentran enormes piedras caídas. Es probable que la comunicación fuera por medio de galerías subterráneas; otra posibilidad, aunque remota, podría ser que ambas unidades no correspondan a la misma época, como lo sugieren las diferencias en los patrones de edificación del Muro A, que presenta más de tres estilos de construcción. Sin embargo, la mayoría de los restos arquitectó-

3 Uno de los felinos, el más grande, se encuentra en poder de Máximo Farro, en Pacopampa. El otro fue traído por Larco Hoyle y actualmente se exhibe en el Museo Larco Herrera en Lima. 


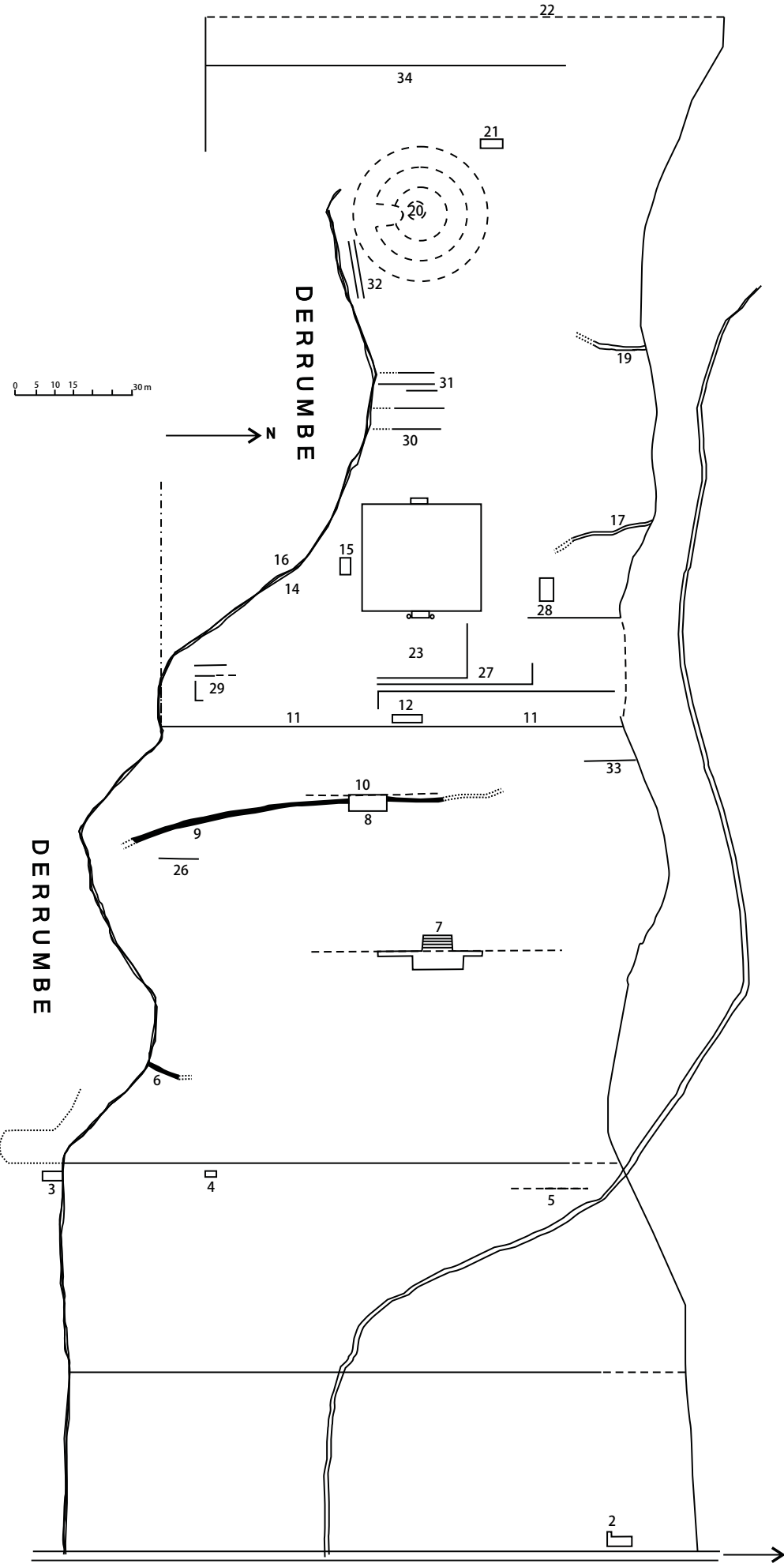

Figura 2. Plano del Templo de Pacopampa con ubicación de unidades de excavación y elementos arquitectónicos. 


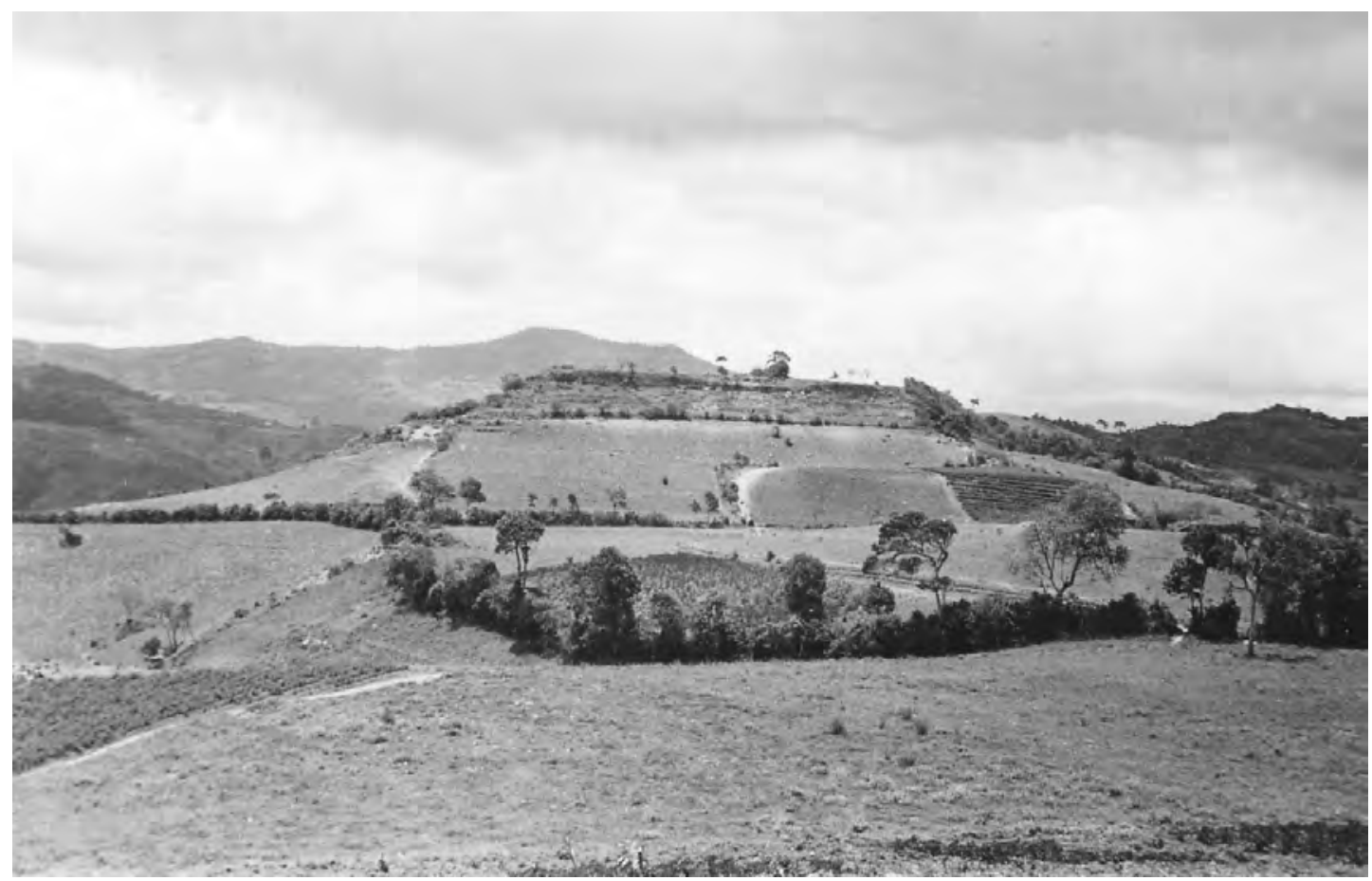

Figura 3. Vista panorámica del lado este del Templo de Pacopampa.

nicos en la tercera plataforma tienen la misma unidad técnica de construcción que los de la segunda plataforma, en especial con la Portada de los Felinos y el Muro B. La disposición de las piedras sigue el mismo ordenamiento técnico, con los muros de la plaza sagrada, en la tercera plataforma.

La galería de la "Serpiente" (denominada así por haberse encontrado una en su interior), explorada y limpiada en los 12 primeros metros, se interrumpe por el desprendimiento de una enorme piedra del techo. Esta galería es probable que comunique a una habitación subterránea. Se encuentra a unos 8 metros del borde este de la plataforma, con entrada hacia el sur al igual que la Galería del Muerto.

\section{Tercera plataforma}

Las evidencias culturales de superficie consistentes en restos de columnas de forma y tamaño variado, cornizas con figuras de felinos y huellas de la planta de los pies, galerías, muchas de ellas estrechas, cimientos de habitaciones de plano rectangular, agrupadas en sectores o circulares como el montículo ubicado al centro del extremo oeste de la plataforma y los resultados asombrosos de nuestras excavaciones, sugieren mayor poblamiento de este sector, confirmándose así nuestra hipótesis inicial de trabajo. Los objetos de superficie son:

- Columna A, ubicada en el extremo sur de la plataforma, junto con otros objetos. Fue llevada a este sitio por el propietario de los terrenos, Máximo Farro. Ignoramos su lugar original. Tiene $50 \mathrm{~cm}$ de diámetro, $2.10 \mathrm{~m}$ de largo y forma cilíndrica. Le falta un fragmento en uno de los extremos que podría ser el descrito en la primera plataforma. Ambos están hechos del mismo material. Carece de decoración.

- Columna B, a 50 metros al norte de la primera, en el centro de la plataforma; se encuentra semienterrada, tiene forma semejante a la anterior pero de tamaño menor a pesar de estar completa; mide 1.50 metros de largo por $50 \mathrm{~cm}$ de diámetro. 
- Columna C, en mal estado de conservación, ubicada al pie del montículo circular. La forma original parece que fue cilíndrica; difícil de medir el diámetro debido a la erosión sufrida; está tallada en roca fosilífera, diferente al material de los anteriores.

- Columna D, Ey F, halladas al centro y a pocos metros del muro B, difieren en forma y dimensiones a las descritas; son mucho más gruesas y probablemente más grandes, en algunas el diámetro llega hasta $75 \mathrm{~cm}$, aparentemente de corte poligonal. ${ }^{4}$

A pocos metros hacia el oeste se descubrió la gran plaza sagrada, de la que tratamos más adelante.

\section{Cortes estratigráficos}

Debido a que el objetivo de nuestro programa de investigaciones era realizar un reconocimiento general del contenido cultural del templo, más que excavaciones extensivas nos limitamos a pequeños cortes estratigráficos exploratorios distribuidos en todo el área ocupada por la construcción, para de este modo conocer su filiación cultural y diferencias ocupacionales con significado temporal, si las hubiere. Pero como la mayor parte de la superficie de las ruinas estaba cubierta con sembríos de alverjas, rakachas, papas y maíz, entre los que se observaban restos de cimientos o pretil de muros, tuvimos que limitar nuestros trabajos a las áreas libres, que ofrecían menor cobertura vegetal y concentración de restos culturales en la superficie.

Se excavaron un total de 15 cortes estratigráficos, distribuidos por toda el área del templo.

La intensiva actividad agrícola había originado disturbios, en especial en los niveles superiores removidos por el arado. Presentaron estratificación positiva C1, C1B, C4, C5, C6, C8, C11 y C12, no así C2, C3, C10; y sin materiales culturales $\mathrm{C} 7, \mathrm{C} 9, \mathrm{C} 13, \mathrm{C} 15$. Las mayores profundidades se encontraron en C5, C1 y C1B, con 2.90,
1.80 y 5.30 metros respectivamente. El más superficial fue $\mathrm{C} 2$, con $50 \mathrm{~cm}$.

Las excavaciones evidenciaron la estratificación de abundante material arqueológico, cerámico, restos óseos, líticos y arquitectónicos. La correlación de cortes, al mostrar similitud o diferencia en la composición cultural, permitió inferir la extensión y preferencia ocupacional a través del tiempo.

Los cortes C1, C1B y C5 tienen estratos con material Pacopampa y Chavín; en cambio, C2 únicamente Chavín y C8, C10, C11, C12, sólo Pacopampa; C3, tiene Chavín y Cajamarca; y C4, Cajamarca sobre Pacopampa.

Además de los cortes, se efectuaron excavaciones en la plaza sagrada, tercera plataforma y Muro A de la segunda terraza. La limpieza proporcionó gran cantidad de restos óseos de camélidos, venados (identificados por el Dr. T. Ueno de la Universidad de Tokyo), y entierros adosados a la pared del Muro B.

\section{Corte 1}

Ubicado a 24 metros al norte de la Columna A, y corniza de los felinos en la tercera plataforma. Dimensiones: 5 x 3 metros y $1.80 \mathrm{~m}$ de profundidad. Se excavó hasta el suelo original, siguiendo los estratos naturales (Fig. 4).

Estrato I.- Tierra negro humosa, mezclada por el arado y endurecida por la lluvia. Su espesor varía entre 15 y $20 \mathrm{~cm}$. En los primeros 10 centímetros, los restos culturales son escasos. Se encuentran mayormente tiestos de cerámica ordinaria, cántaros y ollas de estilo Chavín; cerámica decorada, pasta fina, color marrón o gris, y numerosos huesos de animales.

A medida que se profundiza de 10 a $20 \mathrm{~cm}$, el color de la tierra se torna marrón, compacta, dura de trabajar. Se nota aumento considerable de fragmentos cerámicos, en especial decorados.

\footnotetext{
${ }^{4}$ Larco Hoyle menciona columnas de 3.10 metros de alto y 1.30 de diámetro. La Crónica, setiembre, 1939.
} 


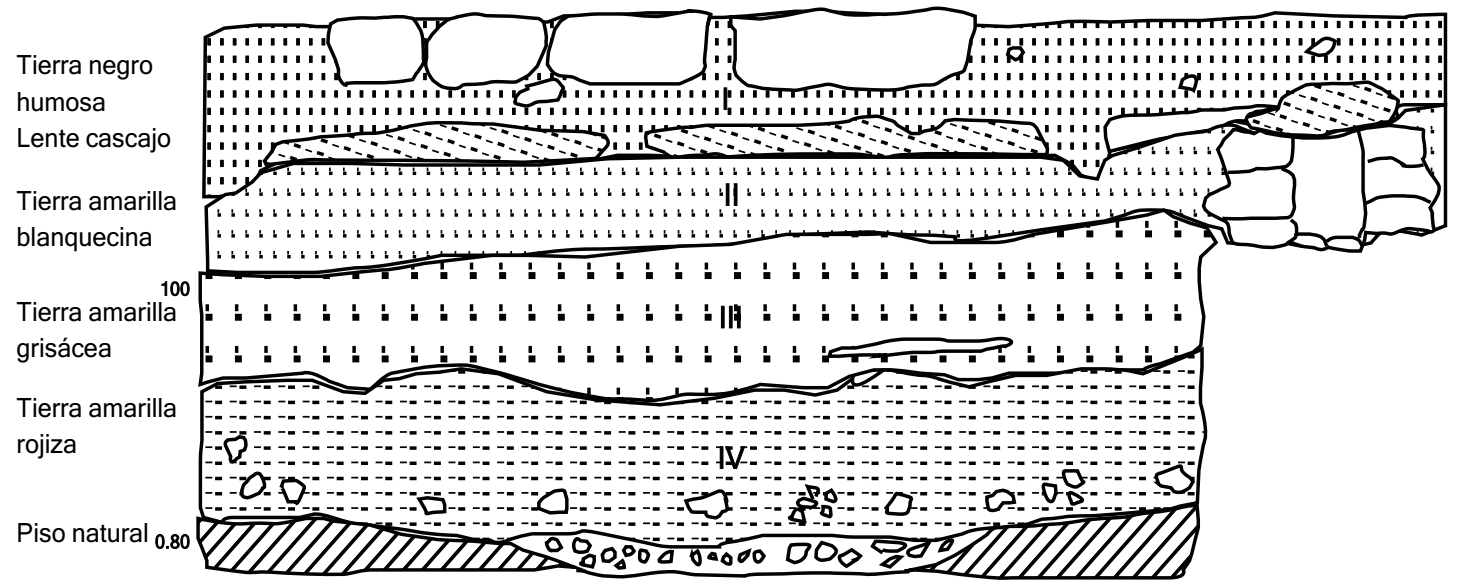

Figura 4. Corte 1, perfil sur.

Estrato II.- Tierra color amarillento con abundante cascajo rojizo. Al iniciarse este estrato, hay una capa delgada $(8 \mathrm{~cm})$, sin contenido cultural, que lo separa del anterior y se extiende a lo largo del cateo. Espesor: entre 20 y $60 \mathrm{~cm}$.

El contenido cultural es completamente diferente al estrato precedente, los rasgos chavinoides están ausentes a pesar de haber numerosa fragmentería incisa. Los motivos decorativos son distintos, grosor y textura más fina y las superficies no son tan bien pulidas.

Estrato III.- La diferencia de éste con el anterior no es muy grande. Hay una ligera variante en el color de la tierra, no obstante ser también amarilla pero más oscura y con tendencia al gris, debido a la gran cantidad de ceniza y carbón vegetal.

Los artefactos también son semejantes, aunque han aumentado los fragmentos con incisiones más profundas y se encuentra mayor variedad de diseños.

Estrato IV.- Tierra amarilla-rojiza, consistencia suave, fácil de excavar, a pesar de la abundancia de pequeñas piedras y cascajo. Los restos culturales disminuyen notoriamente, los tiestos están muy erosionados. Continúan los incisos profundos cortantes pero destacan aquellos pulidos con incisiones delgadas y superficiales.
Estrato V.- Constituido por roce en los extremos y relleno de tierra y cascajo en el centro con numerosas piedras pequeñas. Sin contenido cultural.

\section{Corte 2}

Situado a 6 metros al este del Corte 1 , tercera plataforma. Dimensiones: 3 x 3 m y $50 \mathrm{~cm}$ de profundidad. Se llegó hasta el piso natural.

No obstante la diferente hondura la formación estratigráfica es semejante al anterior. El primer estrato es de tierra removida, marrón oscuro. El espesor varía entre 15 y $20 \mathrm{~cm}$; consistencia suave en los primeros 10 centímetros, dura y mitosa los restantes. Contenido cultural escaso, similar al primer estrato del Corte 1 ; fragmentos de cerámica utilitaria, cántaros de cuello corto y ollas de borde grueso. A partir de los $20 \mathrm{~cm}$ no encontramos ningún artefacto hasta hallar piso natural a los $50 \mathrm{~cm}$.

\section{Corte 3}

Al pie del muro este de la construcción rectangular, y a 35 metros al norte del Corte 2, se ubica el Corte 3. Se eligió este sitio con el objeto de encontrar la galería, que según versiones de los obreros que trabajaron con Larco, comunicaba la "sala de las columnas" con la segunda plataforma. Se profundizó hasta los $2.50 \mathrm{~m}$ sin haber encontrado la supuesta edificación. Los primeros 
30 centímetros son de tierra marrón oscuro, con fragmentos de cerámica estilo Chavín, mezclados con abundante material Cajamarca. En los $2.30 \mathrm{~m}$ restantes no hemos encontrado restos culturales, salvo dos pequeños tiestos color marrón sin decoración. Sin embargo, en todo su espesor está formado por tierra de relleno. No llegamos al piso natural.

\section{Corte 4}

Ubicado con fines exploratorios en uno de los montículos que bordean las ruinas, aproximadamente a $400 \mathrm{~m}$ del lado este de la primera plataforma. Dimensiones: 3 × 3 x 1.20 metros de profundidad. Se llegó hasta el piso natural.

Estrato I.- Tierra mitosa, consistencia dura, difícil de excavar, color marrón oscuro. Espesor: 50 $\mathrm{cm}$. Contenía tiestos de estilo Cajamarca, arcilla fina, tipo caolín, característica de las culturas del Intermedio Temprano de esta región.

Estrato II.- Completamente diferente del anterior. Tierra amarilla con tendencia al gris rojizo. Espesor: 35-45 cm. Carece de materiales Chavín; la fragmentería incisa es estilo Pacopampa.

Estrato III.- Tierra suave, color amarillo rojizo, el espesor oscila entre 40 y $50 \mathrm{~cm}$. Disminución notable de restos culturales; cerámica semejante al anterior.

Estrato IV.- Piso natural, formado por cascajo y roca. Sin contenido cultural.

\section{Corte 5}

Localizado en el ángulo superior sur de la primera plataforma. Dimensiones: 5 x 3 metros y 2.20 $\mathrm{m}$ de profundidad.

Estrato I.-Tierra marrón oscuro, removida por el arado. La cerámica es en su totalidad estilo Chavín. Es notable el hallazgo de un gollete con borde biselado y decoración estilo "rocas" (Lum- breras y Amat, 1969). Se recogió gran número de huesos de venado y otros.

Estrato II.- Tierra amarilla clara, consistencia compacta, difícil de trabajar. En el extremo oeste, encontramos una hilera de piedras, posiblemente corresponde a una pared. El contenido cultural es pre-Chavín, estilo Pacopampa.

Estrato III.- Tierra amarilla grisácea con abundante ceniza y pequeños trozos de carbón vegetal. Continúa el perfil del muro en el extremo este.

La cerámica es semejante al anterior pero aparecen en mayor número los pintados precocción en tres colores: plomo, rojo y naranja. Asimismo, se observan cambios en los motivos decorativos y profundidad de las incisiones.

Estrato IV.- Capa gris oscuro compuesta por tierra amarilla, ceniza y abundante carbón. No se extiende en todos los lados debido a la construcción de la pared.

Los restos culturales no muestran mucha variación. Hay tiestos en dos y tres colores y cerámica con incisiones cortantes y profundas, finas y superficiales, como en el estrato anterior.

Estrato V.- Color rojo amarillento con intrusiones de tierra amarilla a manera de lentes. Espesor: varía entre 1.30 y 2 metros. Notable disminución de tiestos, continúan los incisos cortantes, superficiales y pintados.

Estrato VI.- Tierra de relleno, carece de contenido cultural, salvo la continuación del muro. Abandonamos la excavación por reducción de las dimensiones originales.

\section{Corte 6}

Con fines exploratorios de la construcción circular se cuadriculó el área ubicada al oeste del montículo de la tercera plataforma. Dimensiones: 3 x 1.50 y 1.20 metros de profundidad. 
El contenido cultural es semejante a $\mathrm{C} 1$ y C5, excepto en el hallazgo de una hilera de piedras que parecen ser el cimiento de uno de los muros de la construcción circular. Las piedras son de forma regular, colocadas simétricamente.

\section{Cortes 7, 9, 10, 13 y 15}

Localizados en uno de los montículos mayores contiguos a la tercera plataforma en su extremo oeste. Resultados negativos, sin elementos culturales.

\section{Corte 11}

Situado fuera del área de las ruinas al oeste de la tercera plataforma. Contenía abundante material cerámico y óseos, específicamente preChavín.

Estrato 1.- Tierra amarilla removida por el arado en los $20 \mathrm{~cm}$, mezclada con numerosos fragmentos de cerámica tosca que no tienen semejanza con los provenientes del mismo estrato en los otros cortes, probablemente se relacionan con la cerámica utilitaria pre-Chavín, toscos y gruesos.

Estrato II.- Compuesto de tierra amarilla grisácea y piedras de forma irregular y tamaño pequeño. Gran número de tiestos incisos, profundos y superficiales, además de los utilitarios.

Estrato III. - Naturaleza semejante, salvo el acentuado color grisáceo que le da la abundancia de carbón.

Continúan los tiestos incisos profundos y superficiales y los incisos pintados.

Estrato IV.- Cascajo amarillo rojizo, deleznable, sin material cultural. En el ángulo sur-este aparece la roca natural.

\section{Cortes 8 y 12}

Excavados en la misma zona que los dos anteriores, con idénticos estratos que el $\mathrm{C} 11$. Hemos recogido numerosa fragmentería incisa y pintada en dos y tres colores.
En general, el basural de esta área corresponde a la misma ocupación humana de las ruinas, época pre-Chavín.

En resumen, el templo está ubicado sobre una pequeña colina de naturaleza arcillosa, color amarillo, rojizo y blanquecino; su altura original es desconocida. Los establecimientos sucesivos en el tiempo le han dado la conformación piramidal que tiene en la actualidad.

En las paredes de los cortes ha sido posible reconocer cinco estratos superpuestos, en forma más o menos horizontal, diferenciados en contenido, textura o color en base al dibujo de los perfiles de cada excavación, las notas descriptivas de ellos y las fotografías.

Estrato primero.- Tierra marrón oscuro humosa, muy disturbada por el arado. Filiación cultural: cerámica de estilo Cajamarca, distribución limitada, corresponde a la última ocupación de las ruinas, estratigráficamente asociada a tiestos de estilo Chavín.

Estrato segundo.- Formado por una capa de tierra marrón oscura, casi negra, consistencia dura. Al excavar generalmente se forman terrones debido a la tierra arcillosa que la compone. Espesor: entre 15 y $20 \mathrm{~cm}$. Contenido cultural: cerámica Chavín asociada a numerosos restos óseos. En el corte 1 B alcanza de $80 \mathrm{~cm}$ a 1.10 metros.

Estrato tercero.- Totalmente diferente de los estratos anteriores. Contiene tierra amarilla blanquecina, compacta, puede tener abundante cascajo rojo, escaso carbón. Solo en los cateos 1 y $1 \mathrm{~B}$ están separados por una capa de tierra sin contenido cultural de 8 y $80 \mathrm{~cm}$ de espesor. Espesor: 35 a $45 \mathrm{~cm}$.

Filiación cultural: pre-Chavín o Pacopampa, tiestos incisos de grosor y textura fina, superficie pulida, incisiones cortantes. Frecuentes restos arquitectónicos.

Estrato cuarto.- Naturaleza semejante al anterior, con variación de color, amarillento grisáceo por la abundancia de carbón. 
Filiación cultural: Pacopampa, aumento de incisos cortantes con mayor variedad de diseños; pintados precocción en dos, tres y cuatro colores; restos arquitectónicos.

Estrato quinto.- Yace sobre el piso rocoso estéril, consistente en tierra amarilla-rojiza, escaso carbón, numerosa cantidad de cascajo y piedras. Espesor: 40 a $70 \mathrm{~cm}$.

Filiación cultural: Pacopampa, disminución notoria de tiestos; destacan los incisos cortantes, incisos superficiales y pintados.

\section{Evidencias arquitectónicas}

\section{Muro A (Fig. 5)}

A los 54 metros de exploración del interior de la Galería del Muerto -lado sur-, un derrumbe de la pared oeste y parte de techo, obstruía totalmente el paso. Ante la incapacidad de continuar nuestro recorrido, decidimos limpiar desde el exterior.

El sitio exacto fue localizado siguiendo el eco producido por la percusión hecha desde el interior de la galería.

Una vez señalado el lugar, iniciamos la excavación en un área de $3 \times 3 \mathrm{~m}$. Los trabajos se iniciaron por unidades de $25 \mathrm{~cm}$.

Tierra de color marrón oscuro de consistencia suave y piedras pequeñas, caracterizan los primeros 30 centímetros. El material arqueológico recogido está muy mezclado por la acción del arado, no obstante se observa mayor frecuencia de la cerámica denominada Cajamarca por Reichlen.

La primera evidencia del gran muro, encontrada a los $30 \mathrm{~cm}$ de profundidad, consistía en una hilera de piedras regulares dispuestas en el lado oeste del corte. En un primer momento pensamos que se trataba del pretil de alguna pared. Sin embargo, a los 2 metros de profundidad notamos cambios en el tamaño de las piedras y técnica de aparejo, al igual que irregularidad en la forma, pero no se pudo continuar la excavación de

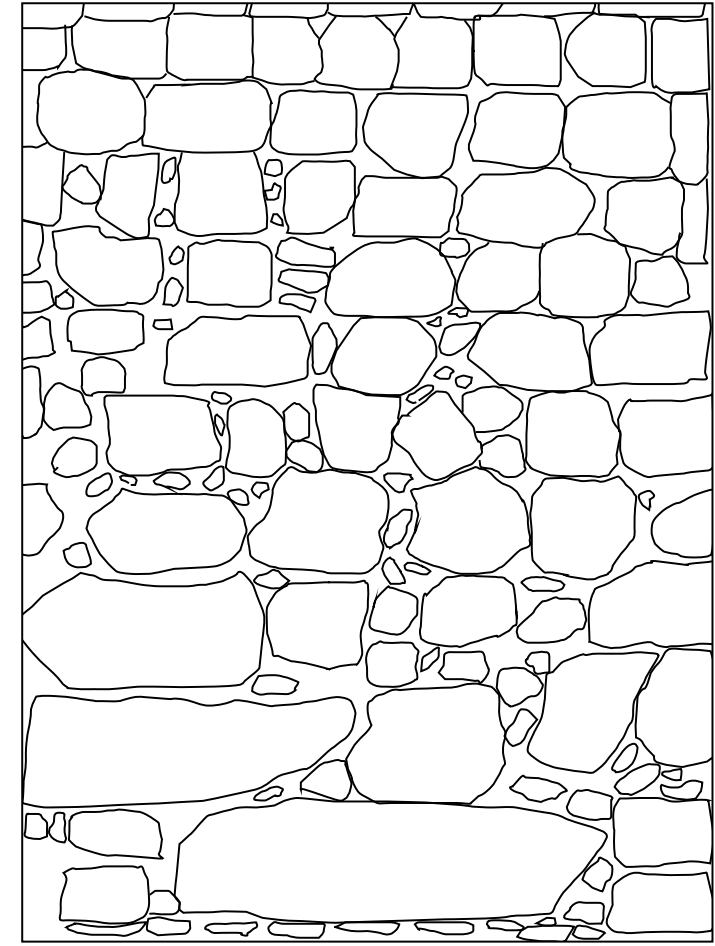

Figura 5. Muro A.

toda el área inicial debido a una piedra, de 2 metros de largo, por 80 de ancho y $25 \mathrm{~m}$ de espesor, que ocupaba el lado norte del cateo, descubierta solo al metro de profundidad y que redujo el área excavable. Por la simetría de sus medidas y calidad de la piedra es semejante al material utilizado en la construcción de las tres primeras hiladas del muro descubierto.

A los $2.60 \mathrm{~m}$ de profundidad -lado surencontramos más de dos piedras largas dispuestas de Este a Oeste perdiéndose en el ángulo sureste. Más tarde, con las excavaciones adicionales, se comprobó que formaban parte del techo de la galería, de allí que tuvimos que ampliar nuestra excavación hacia este lado, logrando ubicar y limpiar la pared caída. No obstante, quedaba la incógnita del gran muro, cada vez más interesante por ofrecer cambios en los patrones de construcción. Fue mayor aún nuestro interés al observar cambios significativos en el contenido cultural y naturaleza de los estratos. 
La tierra de color gris oscuro, que se extiende entre los $30 \mathrm{~cm}$ y $1.40 \mathrm{~m}$, se torna gris amarillenta con intrusiones horizontales de tierra color rojizo de consistencia deleznable (cascajo), utilizado por los chavínes como material de relleno en la construcción de la galería, asociada con tiestos de filiación Chavín, comunes en los niveles superiores.

Continuamos la excavación en profundidad del muro, siendo necesario para ello la reducción del área a $55 \mathrm{~cm}$ de ancho por $3.50 \mathrm{~m}$ de largo, único espacio excavable comprendido entre la parte posterior del muro oeste de la galería y el frente este del Muro A. Prueba de ello son las fotografías tomadas en vertical.

El nivel siguiente carece de restos de ocupación humana y la tierra es de color amarillo rojizo, de consistencia suave. Su espesor oscila entre $45 \mathrm{~cm}$ y $60 \mathrm{~cm}$.

El muro a esta profundidad mantiene su verticalidad, con cambios en la técnica de mampostería, tamaño y forma de las piedras. Después del hiatus cultural, aparecen nuevamente restos de ocupación humana.

El nivel $2.60 \mathrm{~m}-3.10 \mathrm{~m}$ contiene abundante cerámica pre-Chavín, caracterizada fundamentalmente por la ausencia total de la cerámica marrón oscuro y gris del estilo Chavín y la presencia de tiestos pintados precocción en tres colores con diseños geométricos, asociados a grandes piedras de relleno y continúa sin diferencia hasta los $4.95 \mathrm{~m}$ de profundidad, donde un piso de color ladrillo señala el final del Muro A y del relleno.

En conclusión, el hallazgo circunstancial del muro nos ha proporcionado datos valiosos para la reconstrucción de la historia de estos pueblos. El muro en sí, revela por lo menos dos épocas de construcción con patrones diferenciados a través de la técnica y tratamiento del material que se puede sintetizar en:

a) Primera época (Fase Pacopampa), caracterizada por una arquitectura de mampostería ordinaria a base de grandes piedras cortadas en forma irregular, 2 metros de largo por 50 centímetros de ancho, intercaladas con otras piedras más pequeñas como cuña y barro arcilloso en las uniones. Forman mayormente las dos o tres primeras hiladas, asentadas sobre terreno natural. Aproximadamente de los $3.50 \mathrm{~m}$ a $1.10 \mathrm{~m}$, las piedras son canteadas y su tamaño ha disminuido.

b) Segunda época, arquitectura típicamente Chavín, se caracteriza por el empleo de piedras finamente talladas, formas muy regulares, algunas cortadas a escuadra. Constituyen las últimas hiladas del Muro A.

Corresponde a la misma época de construcción del "Templo de las Columnas", la "Plaza Sagrada” y parte del Muro B, que separa la tercera de la segunda plataforma. Las columnas son ubicadas en esta época.

La estratificación confirma esta diferenciación: los $3.40 \mathrm{~m}$ inferiores de la pared estuvieron asociados con materiales pre-Chavín o Pacopampa (Fig. 5); en cambio la continuación hasta la superficie son elementos íntegramente Chavín, salvo el nivel intermedio estéril.

\section{Muro B (118 x 3.50 metros)}

La limpieza de la vegetación que cubría el área comprendida entre la segunda y tercera plataforma dio como resultado el descubrimiento de un gran muro que se desplaza de Norte a Sur, con frente al Este, en una extensión de 118 metros de largo, alcanzando en la actualidad su máxima altura $(3.50 \mathrm{~m})$ en el sector sur. Separa la segunda de la última plataforma.

Los patrones de construcciones, al igual que el material utilizado, no son uniformes. Hay notorias variaciones en tres sectores, que a continuación describimos:

a) Primer sector, comprende los 28 metros iniciales de Norte a Sur. Se caracteriza por el empleo de grandes piedras toscamente trabajadas con un patrón de construcción similar a la arquitectura Tiahuanaco. Se inicia en su extremo norte con una piedra de tamaño mediano, colocada en forma vertical, seguida de una hori- 
zontal, de $2.75 \mathrm{~m}$ de longitud por $80 \mathrm{~cm}$ de alto, que alterna con otra de posición vertical aparejada por una horizontal de $2.20 \mathrm{~m}$ de largo, continuando este mismo orden hasta los $28 \mathrm{~m}$ sur.

b)Segundo sector, hecho de piedras selectas muy bien talladas. En la construcción abandonan el sistema anterior, las piedras son colocadas en forma horizontal, una sobre otra, y llevan como cuña, entre piedra y piedra, delgadas y pequeñas láminas denominadas "pachillas". Abarca $48 \mathrm{~m}$ de largo, comprendidos los $28.70 \mathrm{~m}$ y $76.70 \mathrm{~m}$. Las piedras son mucho más delgadas, mejor trabajadas y de forma más regular que en el sector inicial. La piedra más larga mide $2.90 \mathrm{~m}$, ubicada a 31 metros.

c) Tercer sector, diferenciado de los anteriores por estar construido sin ningún sistema ni orden. Las piedras fueron colocadas sin criterio selectivo y no es raro encontrar pequeñas piedras entre grandes, toscas o labradas, dispuestas indistintamente, más bien como relleno.

A los 85.75 metros sur, se encuentra una piedra amorfa, incrustada en el muro, de $2.50 \mathrm{~m}$ de largo. Originalmente parece que estuvo en posición vertical.

En resumen, el Muro B tiene un largo de 118 metros con una altura máxima de $3.50 \mathrm{~m}$. Las diferencias de estilo y materiales de construcción en los tres sectores probablemente corresponden a diferentes épocas.

Es interesante observar la preferencia de los chavínes por cierta área del muro para enterrar sus muertos. El sector dos está separado del tres por una "pirca" que señala, a su vez, diferencias de función. El sector dos se caracteriza por la presencia de entierros, mientras que el tres, además de un entierro con ofrendas, presenta numerosos fogones que sugieren la ocupación de este lugar como habitación.

\section{La Plaza Sagrada y el Templo de las Columnas}

La adjetivación de la frase obedece mayormente a la necesidad de facilitar una mejor descripción, porque la disposición y naturaleza de las gradas, asociadas a columnas cilíndricas semejantes a las de Chavín de Huántar, el uso de una cantería selecta y la simetría en el ordenamiento de las piedras, forman una sola unidad arquitectónica de apariencia ceremonial, construida probablemente a mediados del Período Formativo, tal vez contemporánea con una de las fases tempranas de la cultura Chavín en Áncash.

Encontrada en forma casual, al igual que el Muro A, en los trabajos efectuados en la tercera plataforma con el objeto de comprobar las versiones de los obreros que participaron en las excavaciones relámpago de Larco Hoyle y que afirmaban (Críspulo Tapia, Conrado Tapia, Carlos Vásquez, etc.) haber descubierto un sistema de graderías interiores que le sugirió a Larco, según los mismos obreros, la existencia de probables habitaciones subterráneas.

La gran plaza ocupa un área de 30 × 30 m ubicada próxima a la esquina sur-este de la tercera plataforma y con una orientación hacia el centro de la misma, formando una sola unidad con el Templo de las Columnas. El sector sur de la explanada se encuentra en la actualidad muy destruido por el deslizamiento de terreno, debido a la pronunciada pendiente del cerro en esta parte. En líneas generales, el conjunto arquitectónico presente las siguientes características:

a) Tiene dos escalinatas, una de entrada al medio del muro oeste y otra de acceso al Templo de las Columnas en el lado opuesto. Ambas constan de tres escalones con 4 metros de largo, hechos en piedra finamente tallada (Fig.6 a, c).

b) De plano cuadrado, con muros de 30 metros que se unen en ángulo recto. En la esquina sur-este se observa una pared anexa cuya función ignoramos. Los muros este y oeste se interrumpen a los 13 metros para dar cabida a las escaleras (Fig. 6b).

c) La construcción sigue el mismo estilo arquitectónico para el primer sector del muro B, o sea que la disposición de las piedras mantienen el orden alternante, vertical-horizontal (Fig. 6d). En el lado este contamos 11 lozas horizontales 
por otras de igual número colocadas verticalmente, siendo la piedra más larga del sector la que tiene $2.30 \mathrm{~m}$, muchas de ellas removidas o fuera de lugar.

d) Parte del piso todavía se encuentra con lozas de piedra, en especial el sector noreste. Las baldosas son de forma irregular, pero de superficie plana.

\section{Grada este}

Tiene un largo de 4 metros. Constituida por 3 pasos, cada uno con tres piedras, una larga al centro y dos pequeñas en los extremos, $1.85 \mathrm{~m}$ de ancho y $1.18 \mathrm{~m}$ de alto. Los escalones tienen semejantes dimensiones salvo ligeras diferencias. Las medidas son:

$\begin{array}{ll}\text { Primer } & \text { a) } 90 \times 51 \times 33 \mathrm{~cm} \text {. } \\ \text { escalón } & \text { b) } 185 \times 50 \times 33 \mathrm{~cm} . \\ & \text { c) } 110 \times 51 \times 32 \mathrm{~cm} .\end{array}$

Segundo

a) $65 \times 70 \times 30 \mathrm{~cm}$.

escalón

b) $240 \times 44 \times 33 \mathrm{~cm}$.

c) $76 \times 60 \times 33 \mathrm{~cm}$.

Tercer

a) $74 \times 40 \times 27 \mathrm{~cm}$.

escalón

b) $210 \times 70 \times 27 \mathrm{~cm}$.

c) $117 \times 70 \times 27 \mathrm{~cm}$.

Las diferencias parciales a la suma total obedece en cada caso a los espacios entre piedras. Ambos brazos de la grada terminan en grandes piedras colocadas verticalmente y en los extremos, columnas.

La grada del lado opuesto tiene similares medidas y características, pero carece de columnas.

\section{Entierros}

En la limpieza del Muro B, segunda plataforma, primero encontramos fragmentos de huesos humanos, mal conservados y dispersos, en una extensión no mayor de un metro cuadrado. La casi total destrucción de las evidencias dificulta- ron el reconocimiento de la forma, orientación y asociaciones culturales.

Posteriormente ubicamos seis entierros en diversos grados de destrucción. Dos de ellos contenían ofrendas de cerámica que permitieron su identificación cultural. Las características generales son:

a) Las fosas fueron cavadas directamente en suelo rocoso, sin una orientación definida.

b) Las dimensiones medias oscilan entre los $60 \mathrm{~cm}$ de largo por $30 \mathrm{~cm}$ de ancho y una profundidad máxima de $50 \mathrm{~cm}$. En ellos han sido depositado los cadáveres.

c) La utilización de lajas de granito "laimosca" como tapas, generalmente en número de tres, semejantes a las lozas usadas con la misma finalidad en Paracas Cavernas, colocadas en forma transversal.

d)Uso de pigmento rojo, probablemente con objeto ritual, aplicado en el cuerpo del cadáver. De los seis entierros, solo dos tenían esta sustancia y precisamente los únicos que llevaban ofrendas, no obstante que los demás se encontraban mejor conservados. La forma de aplicación del colorante es desconocida. Se ha sugerido que el cadáver se cubría totalmente de esta sustancia y que al descomponerse impregnaba los huesos. Otros han postulado a favor de enterramientos secundarios. En el entierro 6 descubrimos que el cadáver tenía en la cavidad bucal un buen trozo de material colorante; al quitarlo observamos que parte de éste se había deslizado y disuelto con la humedad, siendo absorbido por los huesos de la pierna. Contenía dentro un trozo de cristal de roca.

e)Los cadáveres fueron enterrados en posición fetal, con excepción del entierro 5, correspondiente a un niño, quizá de un año, que se encontraba en posición extendida cúbito-dorsal.

\section{Entierro 1}

Localizado a los 58 metros del Muro B; lozas de piedra (granito), de formas regulares halladas en la limpieza del desmonte, asociadas a restos 
óseos y cerámicos, distribuidos en el área de 3 y 4 metros.

Dimensiones:

Largo $\quad 55 \mathrm{~cm}$.
Ancho $30 \mathrm{~cm}$.
Profundidad ?

\section{Asociaciones culturales}

Fragmentos de cerámica llana, factura tosca.

Escasos tiestos decorados con diseños de círculos estampados. En los huesos se identifican fragmentos del cráneo.

\section{Entierro 2}

Excavado en el piso del muro, ubicado a 1 metro de distancia del Entierro 1, lado sur, en condiciones similares y con las mismas asociaciones; los huesos recogidos están en mal estado de conservación.

Dimensiones:

$\begin{array}{ll}\text { Largo } & 58 \mathrm{~cm} . \\ \text { Ancho } & 45 \mathrm{~cm} . \\ \text { Prof. } & 35 \mathrm{~cm} .\end{array}$

Entierro 3

Orientado de Este a Oeste, excavado directamente en la roca, fácil de trabajar cuando está húmeda. La tapa de la fosa, encontrada incrustada hacia el interior, tiene $55 \mathrm{~cm}$ de largo por 25 de ancho y $5 \mathrm{~cm}$ de espesor; tallada en granito.

Dimensiones:

$$
\begin{array}{ll}
\text { Largo } & 85 \mathrm{~cm} . \\
\text { Ancho } & 50 \mathrm{~cm} . \\
\text { Prof. } & 45 \mathrm{~cm} .
\end{array}
$$

\section{Restosóseos}

Un cráneo incompleto de adulto, ubicado en el extremo Oeste, probablemente fuera del sitio original; huesos largos dispersos, algunos cubiertos con el colorante rojo.

\section{Ofrendas}

Taza de arcilla de silueta curvada hacia la base, borde directo, labio redondeado, base con- vexa, $67 \mathrm{~mm}$ de grosor, color negro, superficie externa e interna finamente pulida, decorada a base de círculos estampados que, formando una banda limitada por dos líneas incisas, circunda el área Chavín-Kotosh y "Rocas" en la secuencia tipológica de Chavín de Huántar.

\section{Entierro 4}

Ubicado a 1 metro del Entierro 3, lado sur, muy destruido. Los restos óseos, algunos calcinados, se encuentran dispersos en un área de dos metros cuadrados, asociados a fragmentos de cerámica llana y abundante ceniza. Parece que el mismo lugar sirvió de fogón a grupos posteriores. Por el nivel en el que se encuentra y el tipo de asociaciones, lo incluimos cronológicamente en el grupo de los anteriores. Sin embargo, no ha sido posible determinar las dimensiones de la fosa.

\section{Entierro 5}

A escasos metros del Entierro 4. Exteriormente se hallaba intacto, las lajas de piedra en perfectas condiciones, colocadas en forma horizontal en número de tres. La fosa fue cavada en la roca, debajo del piso del muro, orientada de Norte a Sur.

Dimensiones:

$$
\begin{array}{ll}
\text { Largo } & 75 \mathrm{~cm} . \\
\text { Ancho } & 38 \mathrm{~cm} .
\end{array}
$$

Prof. $\quad 25 \mathrm{~cm}$ (en el interior la medidas son irregulares).

Las lozas que sirven de tapa tienen las siguientes dimensiones:

a) $49 \times 25 \times 6 \mathrm{~cm}$.

b) $49 \times 25 \times 7 \mathrm{~cm}$.

c) $36 \times 22 \times 6 \mathrm{~cm}$.

\section{Restosóseos}

Cráneo de niño, ubicado en el extremo norte, con la frente hacia el Sur; parte del cuerpo se encuentra semi-cubierto por barro a lo largo de la pequeña fosa. Los huesos se desintegran al simple contacto, lo que dificulta su medición. 

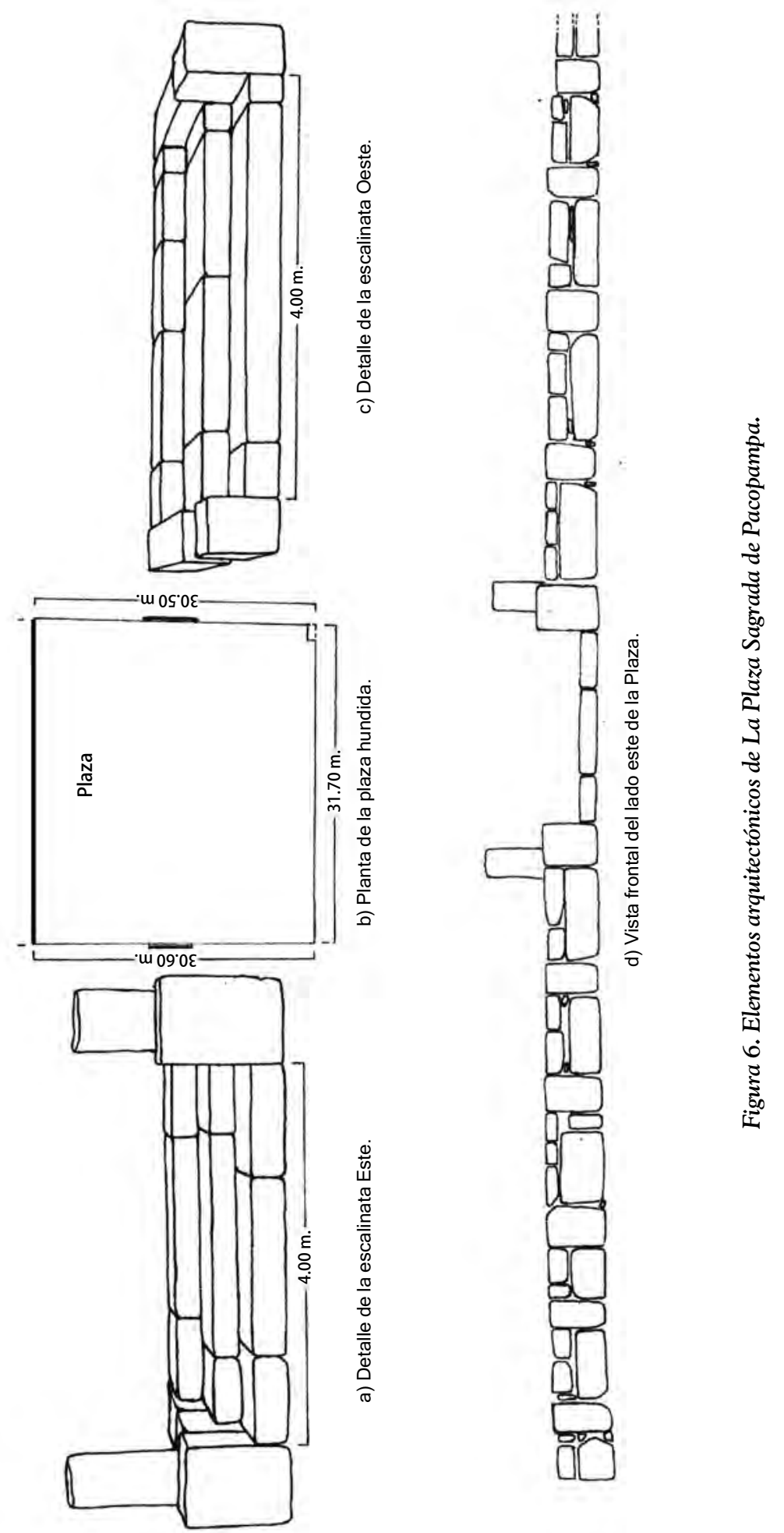


\section{Asociaciones culturales}

Ninguna. Se trata del enterramiento de un infante, cuyos restos se encuentran en proceso de desintegración. El cadáver fue orientado de Norte a Sur, sin ofrendas.

\section{Entierro 6}

A los 95 metros de limpieza del Muro B y a 30 metros del Entierro 5, se encontró una piedra alargada y laminada en posición vertical. Por las características había la posibilidad de encontrar una tumba, y así fue. También se ubicó otra piedra semejante en posición horizontal, paralela al muro. Despejada la cubierta exterior de las piedras, quedó la tapa de la fosa.

Las medidas de las piedras son:

a) $70 \times 30 \times 2 \mathrm{~cm}$.

b) $65 \times 40 \times 5 \mathrm{~cm}$.

Dimensiones:

$$
\begin{array}{ll}
\text { Largo } & 80 \mathrm{~cm} . \\
\text { Ancho } & 60 \mathrm{~cm} . \\
\text { Prof. } & 50 \mathrm{~cm} .
\end{array}
$$

El entierro se hallaba en el extremo este, removido y disturbado. Los restos óseos se encontraban fuera de lugar y había desaparecido la tercera parte.

\section{Restos óseos}

Después de quitar las lozas que servían de tapa, encontramos tierra compacta dura de trabajar color café y amarilla por sectores. A los 20 $\mathrm{cm}$ de profundidad, en el lado oeste de la fosa, hallamos una taza de arcilla color negro, colocada boca abajo, cubriendo la cara del cadáver. Hacia el lado opuesto los huesos fueron recogidos en desorden, algunos estaban pintados de rojo. Al levantar la ofrenda la cara se encontraba en regular estado de conservación y al limpiar la tierra, observamos que un trozo de material rojo llenaba la cavidad de cristal de roca. Un fragmento de la mandíbula, incrustado a la altura del cuello, evidencia que una parte del colorante se había deslizado hacia el interior del cuerpo y disuelto por el agua del subsuelo; fue absorbida por los huesos.

El cadáver fue enterrado probablemente en posición fetal, con vista hacia el Este. Lo deducimos por la orientación del cráneo, porque esta parte del entierro no ha sido afectado por la caída de las piedras del Muro B. Los restos óseos corresponden a un adulto.

\section{Evidencias culturales}

Taza de color negro con manchas grises en la superficie externa, borde expandido hacia la boca, labio rebajado exteriormente, base plana, decoración bruñida.

Dimensiones:

$\begin{array}{ll}\text { Altura } & 7 \mathrm{~cm} . \\ \text { Diámetro } & 14 \mathrm{~cm} \text { (boca). } \\ \text { Diámetro } & 9.8 \mathrm{~cm} \text { (base). } \\ \text { Espesor } & 97 \mathrm{~mm} .\end{array}$

Superficie finamente pulida.

Es probable que el colorante y el trozo de cristal hayan tenido función ritual, quizá relacionada con una ceremonia acerca de la inmortalidad.

\section{Cerámica}

Debido a que una parte del material no ha sido aún trasladado a Lima, presentamos este primer informe en estado preliminar, basado en observaciones y notas durante el proceso de excavación y el estudio del material parcial. Por ello omitimos los índices y diagramas estadísticos que muestran cuadros significativos de los cambios operados en los tipos a través del tiempo. Es probable que alguno de ellos sea modificado en el futuro, después del análisis de la muestra total.

En la clasificación y descripción hemos establecido tentativamente dos fases ("unidad más pequeña de medida de la variación cultural en la escala espacio-temporal...") $)^{5}$, a las cuales corresponden determinados tipos de cerámica. Esta secuencia se basa en excavaciones estratigráficas de 15 pozos, distribuidos en diferentes sectores

\footnotetext{
5 Willey y McGimsey, 1954, p.6.
} 
del sitio y cuyo espesor varía de $50 \mathrm{~cm}$ a $2.90 \mathrm{~m}$ de profundidad.

Clasificamos los tipos en base a diferencias en pasta, tratamiento de superficie, forma y decoración.

\section{Fase Pacopampa}

Está conformada por toda aquella cerámica que participa de un mismo estilo y que difiere de las fases consideradas más temprana de Kotosh y Chavín.

La estratificación de los pozos presenta 1.70 $m$ de acumulación vertical anterior a la presencia de elementos Chavín. Los cambios que se perciben en la cerámica señalan hacia futuras divisiones de la fase que serán concretadas al término del estudio del material.

Son rasgos ceramográficos comunes a esta fase:

\section{Pasta}

Manufactura: enrollada, sin huellas de unión, temperante calcáreo, muy menudo, consistencia deleznable, distribución uniforme. Predominan las vasijas abiertas de color marrón o rojo con borde directo, labio redondeado, aunque son frecuentes los labios lobulados, dentados y aquillados; la cocción es mayormente defectuosa, reducida u oxidada; el tratamiento de la superficie es variado según los tipos, desde un alisado tosco a un pulido opaco y un buen pulido.

Es muy elevado el porcentaje de vasijas decoradas, generalmente limitada a la superficie externa entre el borde y la parte media del cuerpo, rara vez en la base o el interior. Las técnicas decorativas son: inciso cortante, inciso superficial, exciso, peinado, brochado, pulido estriado, tiras sobrepuestas, inciso policromo, pintado post-cocción y escasos punteados. La pintura precocción, separada por incisiones en bandas de dos, tres o cuatro colores, aparece desde niveles inferiores y tiende a desaparecer al término de la fase, al igual que los bordes pintados de rojo. Se encuentra diversidad de motivos geométricos y en menor cantidad figurativos. Es interesante anotar que aproximadamente desde la parte media de la fase aparecen representaciones felínicas de perfil o de frente. En el exterior de las vasijas, muchas veces los bordes de los bols siguen el contorno de la figura o son escalonados, dentados. Los diseños antropomorfos son menos frecuentes, pero aparecen desde más temprano.

\section{Pacopampa alisado}

\section{Pasta}

Manufactura: Enrollada.

Temperante: Granos de caliza asociados con partículas de roca grisácea; en menor cantidad los que llevan mica, partículas oscuras con intrusiones de roca caliza y finas partículas blancas o rojas.

Textura: Diversa, según el temperante y cocción. La pasta que tiene desgrasante blanco yesoso es regularmente deleznable, aunque de uniforme dispersión; en cambio la de mica es más compacta y dura de cortar. Espesor: 33 a 110 $\mathrm{mm}$.

Color: Puede ser rojo, marrón o gris.

Cocción: Predominan los tiestos oxidados; mal cocidos.

\section{Superficie}

Color: No es uniforme, un mismo tiesto tiene dos o más tonalidades. Ambas superficies pueden ser rojas o marrones, algunas con manchas oscuras, escasos de color gris.

Tratamiento: La superficie exterior es irregular, varía de alisado a pulido opaco; el interior generalmente es alisado con huellas pronunciadas del implemento usado en vasijas cerradas. Los bordes de los cántaros siempre son pulidos.

Dureza: 2 a 2.5 en la escala de March. 


\section{Forma}

Predominan las vasijas cerradas, ollas de borde en coma, labios redondeados, biselados interiormente o aplanados, lados curvados hacia el interior, forma elipsoide horizontal. Espesor: $92 \mathrm{~mm}$ a $110 \mathrm{~mm}$.

- Ollas de borde en coma, engrosado interiormente hasta alcanzar un espesor de $160 \mathrm{~mm}$ a $210 \mathrm{~mm}$, mientras en el cuerpo, solo de $70 \mathrm{~mm}$ a $112 \mathrm{~mm}$; labio redondeado o aplanado, lados curvados hacia el interior, forma elipsoide horizontal, base convexa. Diámetro de boca: $28 \mathrm{~cm}$.

- Jarras de cuello corto, cuerpo globular, borde invertido, labio redondeado (largo del cuello varía entre $370 \mathrm{~mm}$ y $400 \mathrm{~mm}$ ).

Entre las vasijas abiertas:

- Platos de borde directo, labio redondeado o biselado exteriormente, lados divergentes, base probablemente convexa. Espesor: 48 a $64 \mathrm{~mm}$; diámetro de boca: 23 a $44 \mathrm{~cm}$.

- Bols de borde directo, labio engrosado exteriormente, lados divergentes, alcanza en la boca $178 \mathrm{~mm}$ de espesor y 50 a $80 \mathrm{~mm}$ en el cuerpo. Diámetro de la boca: $40 \mathrm{~cm}$.

\section{Pacopampa inciso cortante (Figs. 7-10)}

\section{Pasta}

Manufactura: Enrollada.

Temperante: Casi uniforme en toda la muestra, granulado fino, blanquecino, con intrusiones de partículas rojas. En menor proporción los tiestos con abundante granos negros y aquellos constituidos de cuarzo.

Textura: Diversa, según la clase del desgrasante; medianamente compacta en los primeros, porosa y deleznable en los segundos, y compacta en los últimos. En general, la distribución es uniforme, sin bolsas de aire, fractura irregular. Espesor: 33 a $58 \mathrm{~mm}$.

Color: Predominan los rojos y marrones, en menor cantidad los grises.
Cocción: Mayormente oxidada, cocimiento defectuoso con el centro gris; entre los reducidos escasos tienen el núcleo anaranjado.

\section{Superficie}

Color: Puede ser:

- Interior y exterior rojo uniforme.

- Exterior rojo con manchas grises; interior rojo o gris oscuro.

- Exterior marrón oscuro con manchas grises, interior igual o gris.

- Interior y exterior gris con sectores claros.

Tratamiento: Superficie externa áspera, pulido opaco con huellas del instrumento utilizado, en algunos es visible el temperante. La superficie interna y el borde de las vasijas abiertas frecuentemente bien pulidas, y pulido opaco o alisado en las cerradas. En menor proporción las vasijas que tienen ambas superficies engobadas de rojo y bien pulidas.

Dureza: 2 a 2.5 en la escala de March.

\section{Forma}

- Bols de borde expandido, engrosado hacia la boca, labio redondeado, biselado exteriormente o aplanado con acanaladura central; lados rectos hacia la base, expandido hacia el borde, base aplanada. Espesor: $35 \mathrm{~mm}$ a $52 \mathrm{~mm}$; diámetro de boca: $25 \mathrm{~cm}$.

- Bols de borde directo, labio redondeado, aplanado, biselado o adelgazado, lados divergentes, base aplanada. Espesor: $27 \mathrm{~mm}$ a $58 \mathrm{~mm}$.

- Bols de borde vertical, labio redondeado o adelgazado, lados casi rectos, ligeramente curvados hacia la boca.

- Bols de borde directo, labio redondeado, lados curvados hacia la base, que probablemente sea convexa.

- Bols de borde directo o labio aquillado, lobulado o dentado, base convexa o aplanada.

- Platos de borde directo o expandido, labio redondeado, biselado o aplanado, lados diver- 
gentes, base probablemente convexa. Espesor: $30 \mathrm{~mm}$ a $65 \mathrm{~mm}$; diámetro de boca: 25 a $27 \mathrm{~cm}$.

- Jarras de cuello corto, $35 \mathrm{~mm}$ de longitud, borde directo, expandido o evertido, labio redondeado, cuerpo esférico.

\section{Decoración}

Técnica: Incisiones cortantes, anchas y profundas $(11 \mathrm{~mm}$ a $32 \mathrm{~mm}$ de ancho por 9 a $23 \mathrm{~mm}$ de profundidad), trazo irregular, cama áspera, sobre superficie externa de pulido opaco. Solo un tiesto tiene decoración interna debajo del labio y otro está asociado con incisiones angostas y superficiales (Hatching), que agrupadas en 4 cubren el interior del diseño.

Motivos: Geométricos y figurativos.

\section{a) Geométricos}

- Sucesión horizontal de emes entrelazadas que se combinan con un círculo u oval y están limitadas en el extremo superior por una recta.

- Una sola línea horizontal, banda ancha o sucesión de bandas angostas de tamaño variable en un mismo tiesto, circunda el área exterior debajo del labio.

- Cuadrados o rectángulos simples o concéntricos, muchos de los cuales parecen formar ojos.

- Círculos concéntricos simples o en relieve de contorno irregular, pueden llevar puntos o dos rayitas verticales en el centro, limitados por dos o más líneas incisas debajo del labio.

- Escalones simples, dobles o enlazados, con rayas en el centro.

- Líneas diagonales paralelas y entrecruzadas.

\section{b) Figurativos}

- Caras felínicas ejecutadas de perfil en el exterior de las vasijas abiertas; rectángulos concéntricos forman los ojos, una voluta o nostril la nariz y la boca lleva colmillos.

- Caras felínicas sobre el exterior de vasijas abiertas de frente y en forma alterna, de modo que tenemos la figura en posición normal e invertida. Generalmente, trapecios, triángulos o círculos figuran al contorno de la cabeza, llevando dos círculos simples por ojos, dos rayitas verticales por nariz y una recta curvada hacia arriba en sus extremos de boca. Apéndices, alas y otros elementos incompletos.

- Ojos rectangulares u ovales con la pupila excéntrica; dientes, boca o manos como elementos decorativos aislados.

- Combinación de líneas angostas y anchas, formando diseños reticulados.

\section{Pacopampa inciso policromo}

\section{Pasta}

Manufactura: Enrollada.

Temperante: Granulado blanquecino con intrusiones rojas.

Textura: Distribución uniforme del desgrasante. Espesor: 35 a $52 \mathrm{~mm}$.

Color: Rojizo con banda central gris.

Cocción: Oxidación defectuosa, rara vez reducida.

\section{Superficie}

Color: Puede ser bicolor o tricolor. Exterior pintado, precocción de rojo claro, rojo indio, plomo o blanco; interior blanco o plomo; exterior rojo indio, rojo claro y ante; interior rojo claro.

Tratamiento: Ambas superficies muy bien pulidas y pintadas antes de la cocción.

Dureza: 2 a 2.5, escala de March.

\section{Forma}

- Platos de borde directo, labio plano, lados divergentes, base aplanada. Grosor: $42 \mathrm{~mm}$ a 62 $\mathrm{mm}$, diámetro de boca: $23 \mathrm{~cm}$ a $25 \mathrm{~cm}$. 


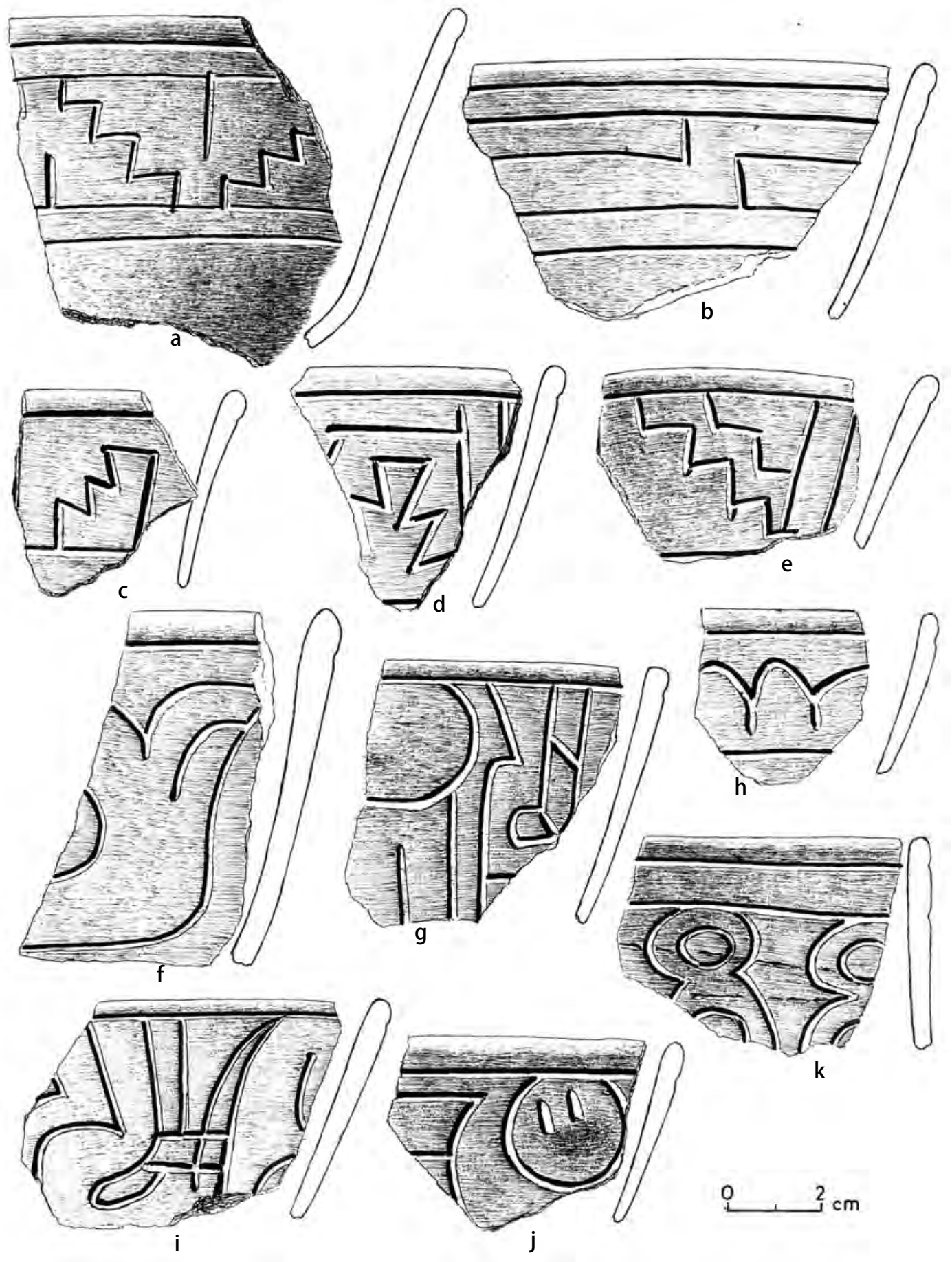

Figura 7. Cerámica de la Fase Pacopampa, tipo inciso cortante: Diseños escalonados (a-e); emes enlazadas (f, h); círculos en relieve, inciso (j); figuras felínicas $(g, i)$. 

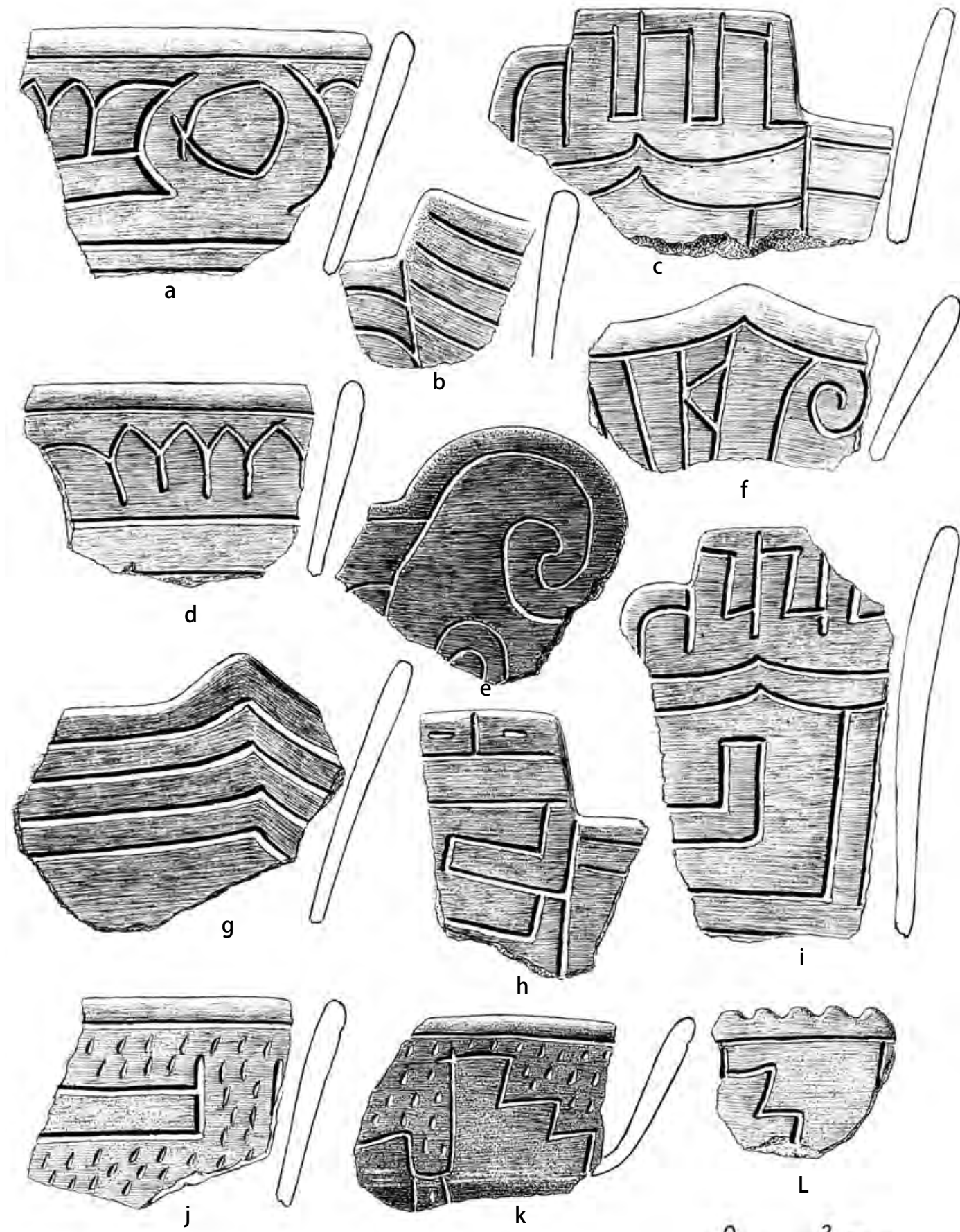

b

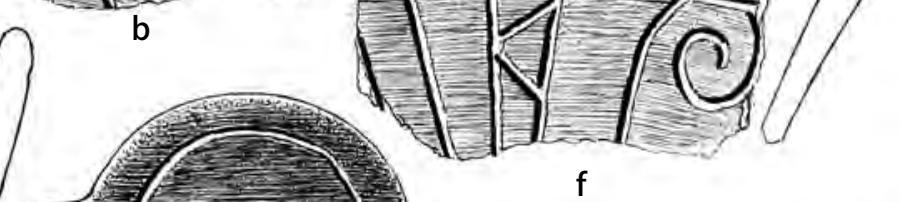

$f$
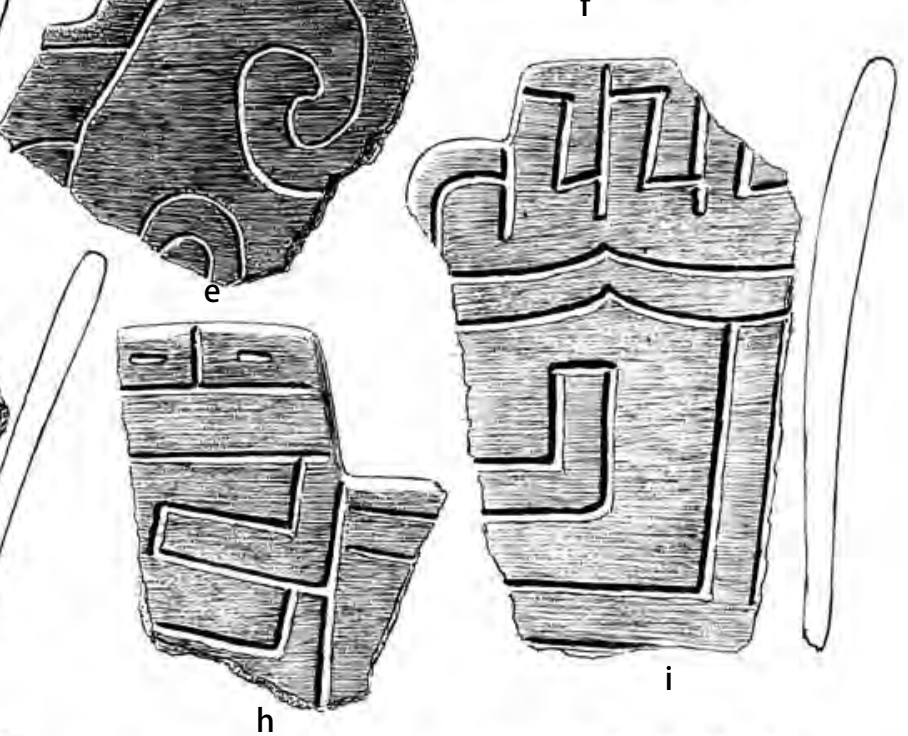

$\mathrm{h}$
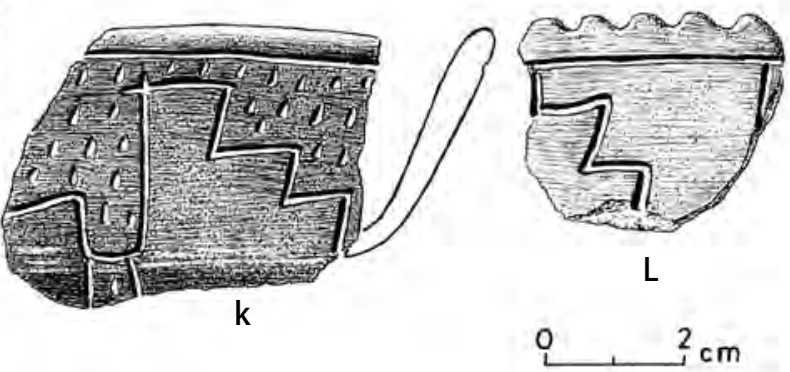

Figura 8. Cerámica de la Fase Pacopampa, tipo inciso cortante: Diseños de emes enlazadas (a,d); labios escalonados (b-c, h-i); labio lobulado (e); labios aquillados ( $f-g)$; punteado en zonas (j-k); labio dentado (l). 

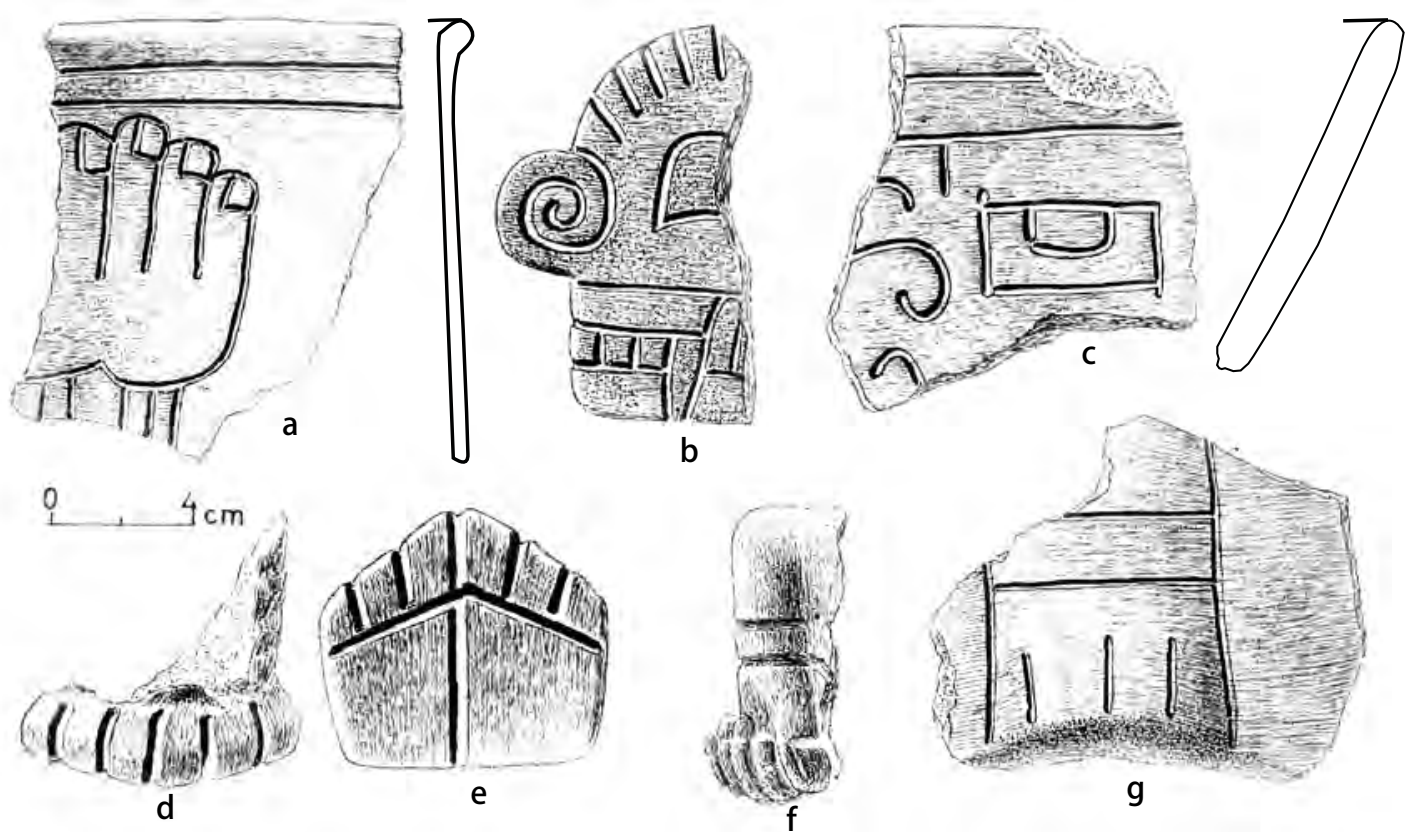

b
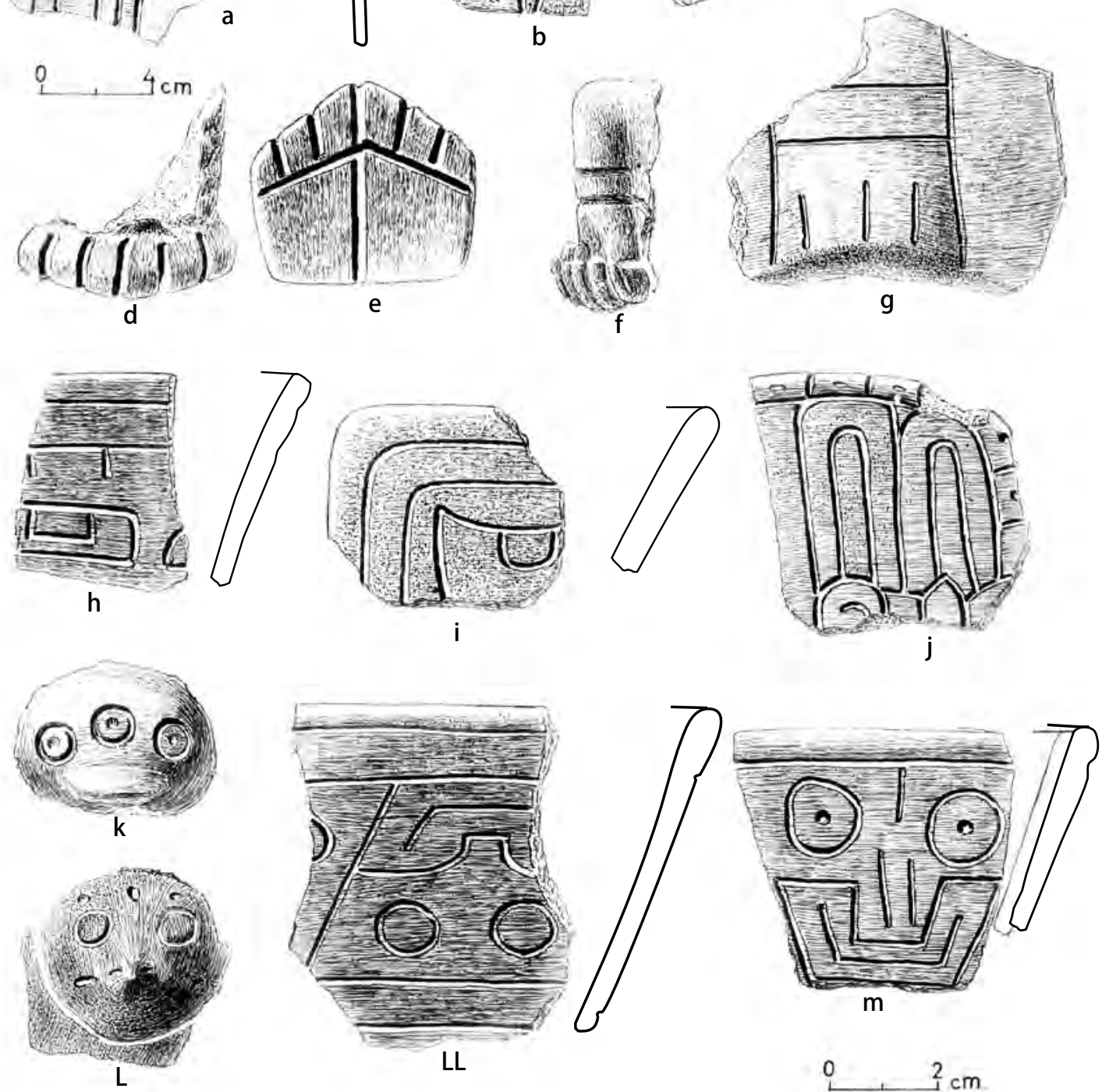

Figura 9. Cerámica de la Fase Pacopampa: Diseños figurativos tipo inciso cortante (a-c, g-j, ll-m); diseños misceláneos $(d-f, k-l, b, c, h)$. 
- Platos de borde inclinado hacia el interior, labio redondeado, base aplanada. Espesor: 48 $\mathrm{mm}$ a $52 \mathrm{~mm}$; diámetro de boca: $25 \mathrm{~cm}$.

\section{Decoración}

Técnica: Incisiones delgadas efectuadas cuando la arcilla estaba en proceso de secado, cama de trazo irregular, separan áreas pintadas de rojo, ante, rojo indio, blanco y plomo. Los colores siempre se alternan. Labio especialmente pintado de rojo.

Motivos: Bandas y diseños rectangulares, algunos concéntricos.

\section{Pacopampa inciso superficial (Figs. 10-11)}

\section{Pasta}

Manufactura: Enrollada.

Temperante: Granulado, blanquecino, abundante y fino; negruzco en menor cantidad.

Textura: Casi deleznable, homogénea dispersión del antiplástico. Espesor: 25 mm a 62 mm.

Color: Varía de gris oscuro y claro a marrón y rojo, con predominio de los últimos.

Cocción: Oxidada y reducida.

\section{Superficie}

Color: Puede ser:

- Exterior e interior marrón o rojo.

- Ambas superficies grises.

- Exterior rojo, marrón o gris, exterior gris o rojo respectivamente.

Tratamiento: Superficie finamente pulida, en especial el interior de las vasijas abiertas, y alisado estriado en las cerradas. Un reducido número lleva engobe rojo.

Dureza: 2 a 2.5, escala de March.

\section{Forma}

El 80\% de las vasijas son abiertas.

- Bols de labio biselado o redondeado, lados rectos hacia la base, engosados y expandidos en la boca. Espesor: $35 \mathrm{~mm}$ a $45 \mathrm{~mm}$.

- Bols de borde directo, labio redondeado, biselado o adelgazado, lados divergentes. Grosor: 32 $\mathrm{mm}$ a $42 \mathrm{~mm}$.

- Bols de borde vertical, labio redondeado, adelgazado o biselado, lados rectos. Grosor: $35 \mathrm{~mm}$ a $50 \mathrm{~mm}$.

- Bols de borde invertido, labio biselado o adelgazado, lados convergentes. Espesor: $37 \mathrm{~mm}$ a 43 $\mathrm{mm}$.

- Platos de borde directo, labio redondeado o biselado interiormente, lados divergentes, grosor $35 \mathrm{~mm}$ a $39 \mathrm{~mm}$; diámetro de boca: $34 \mathrm{~cm}$.

\section{Decoración}

Técnica: Incisiones angostas, finas y superficiales $(5 \mathrm{~mm}$ a $7 \mathrm{~mm}$ de ancho por $2 \mathrm{~mm}$ de profundidad), sobre superficie externa bien pulida.

\section{Motivo}

- Emes entrelazadas dentro de una banda o limitadas en el extremo superior por una recta.

- Aplicaciones debajo de la recta que bordea el área inferior del labio. Se han adherido pastillas de arcilla limitadas por incisiones, dejando círculos irregulares en relieve.

- Líneas horizontales que en número de una o más bordean el área media superior de la vasija.

- Combinación de líneas y círculos concéntricos irregulares o líneas quebradas.

- Simples rayas discontinuas.

- Bandas sombreadas (Hatching).

- Diseños escalonados paralelos parten de una recta, debajo del borde.

\section{Pacopampa llano}

Pasta

Manufactura: Enrollada. 


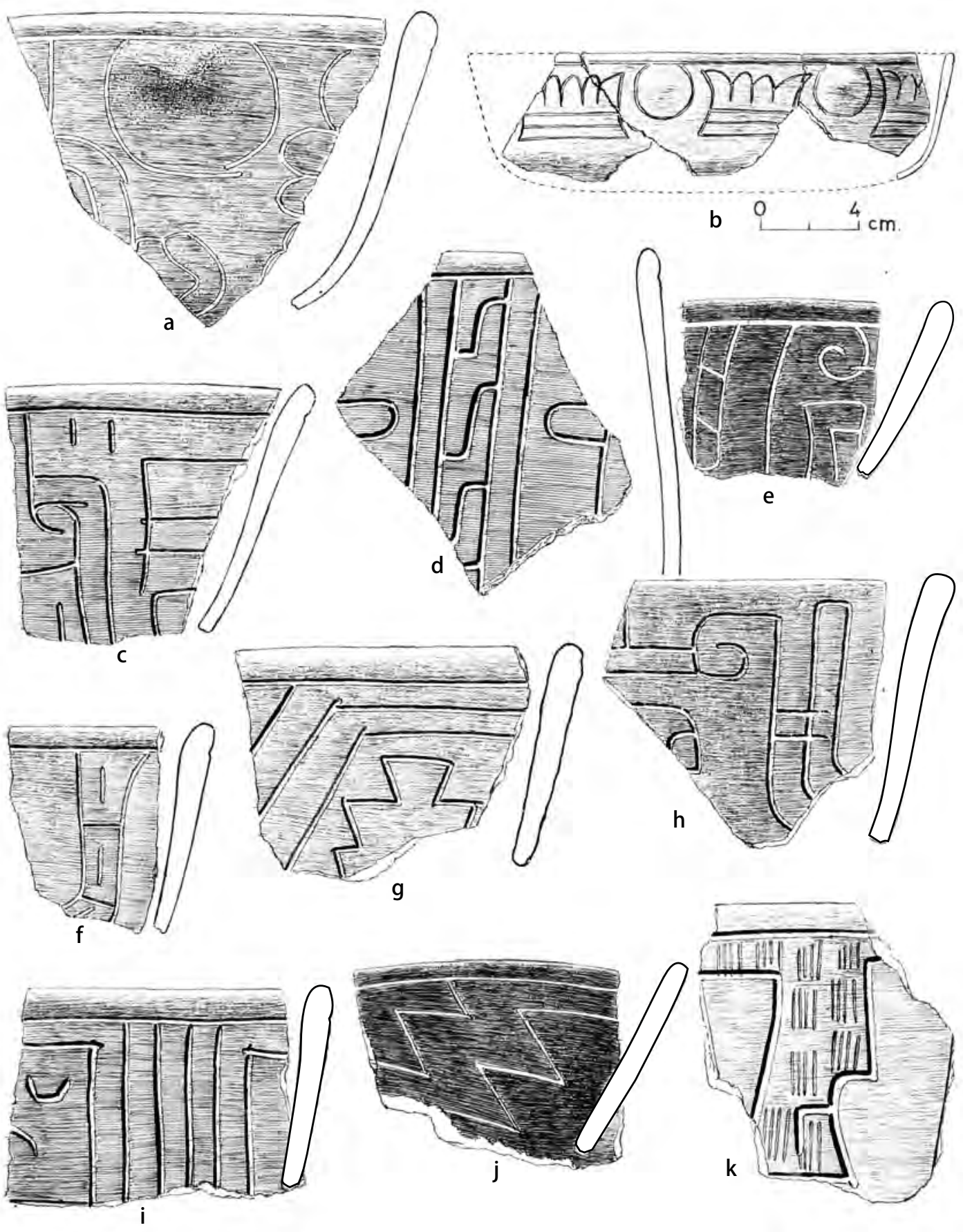

Figura 10. Cerámica de la Fase Pacopampa: a-b, e-f, j. Tipo inciso superficial; c-d, g-i, k. Tipo inciso cortante. 
Temperante: Puede ser granulado blanquecino, abundante; cuarzo brillante muy visible en la superficie o fino grisáceo con partículas negras.

Textura: Homogénea distribución del antiplástico, estructura medianamente compacta.

Espesor: $35 \mathrm{~mm}$ a $60 \mathrm{~mm}$.

Color: Dos variedades: a) gris claro u oscuro; b) rojizo o marrón.

Cocción: Reducida y oxidada deficiente.

\section{Superficie}

Color: Exterior rojizo, algunos con manchas grises; interior rojo o gris.

Tratamiento: Superficie externa pulida, escasos bien pulidos; interior mejor pulido en las vasijas abiertas, alisado en las cerradas. Algunas llevan ambas superficies engobadas de rojo.

Dureza: 2.5 en la escala March.

\section{Forma}

Predominan las vasijas cerradas.

- Jarras de cuello corto, $144 \mathrm{~mm}$ de longitud, borde evertido o expandido, labio redondeado, lados del cuello constreñidos en la parte media. Grosor: $45 \mathrm{~m}$ a $55 \mathrm{~mm}$, cuerpo esférico.

- Jarras de cuello corto (255 mm de largo) borde directo, labio redondeado, cuerpo globular. Espesor: $45 \mathrm{~mm}$ a $53 \mathrm{~mm}$; diámetro de boca: $14 \mathrm{~cm}$.

- Fragmento de asa estribo, borde vertical, labio redondeado. Espesor: $34 \mathrm{~mm}$ a $41 \mathrm{~mm}$.

- Bols de borde directo, labio redondeado, lados divergentes; la base puede ser aplanada. Espesor: 34 a $41 \mathrm{~mm}$; diámetro de base $21 \mathrm{~cm}$.

- Bols de borde directo, labio redondeado o biselado, lados divergentes. Espesor: 48 a $51 \mathrm{~mm}$.

- Bols de borde expandido, labio redondeado, lados engrosados hacia la boca, alcanzando 103 $\mathrm{mm}$ de grosor y $50 \mathrm{~mm}$ en el cuerpo.
- Platos de borde directo, labio redondeado, lados divergentes. Espesor: $39 \mathrm{~mm}$ a $43 \mathrm{~mm}$, base convexa.

- Ollas, borde en coma, labio redondeado, cuerpo esférico. Espesor: $43 \mathrm{~mm}$.

\section{Pacopampa pintado post-cocción (Fig. 12)}

\section{Pasta}

Manufactura: Enrollada.

Temperante: Granulado, blanquecino, abundante.

Textura: Medianamente deleznable, distribución uniforme. Espesor: $26 \mathrm{~mm}$ a $42 \mathrm{~mm}$.

Color: Marrón y gris.

Cocción: Mal oxidada y reducida.

\section{Superficie}

- Exterior marrón, interior gris, algunos con manchas rojas de cocción.

- Ambas superficies, gris claro.

Tratamiento: Áreas de pulido tosco contrastan con zonas pintadas de rojo post-cocción; interior muy bien pulido.

Dureza: 2 a 2.5, escala de March.

\section{Forma}

- Bols de borde engrosado, directo o expandido, labio redondeado, dentado; lados divergentes, base probablemente convexa o aplanada.

- Platos de borde inclinado hacia el exterior, labio redondeado. Espesor: $42 \mathrm{~mm}$ a $59 \mathrm{~mm}$; diámetro de boca: 38 a $40 \mathrm{~cm}$.

\section{Decoración}

Técnica: Sobre superficie áspera se han trazado incisiones cortantes, anchas y profundas, de trazo irregular, que separan áreas pintadas de rojo post-cocción. 

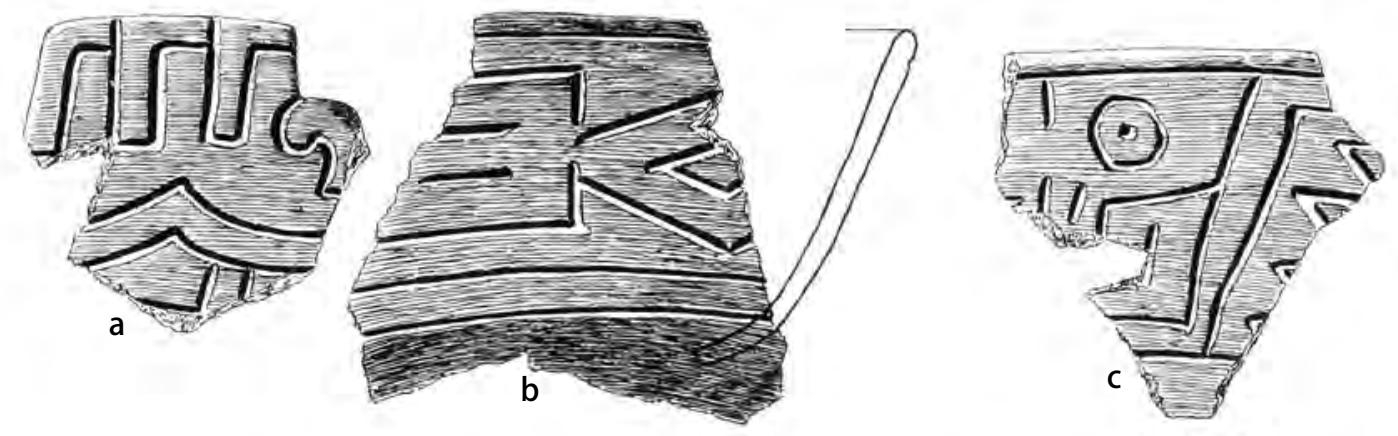

$0 \quad 12 \mathrm{~cm}$
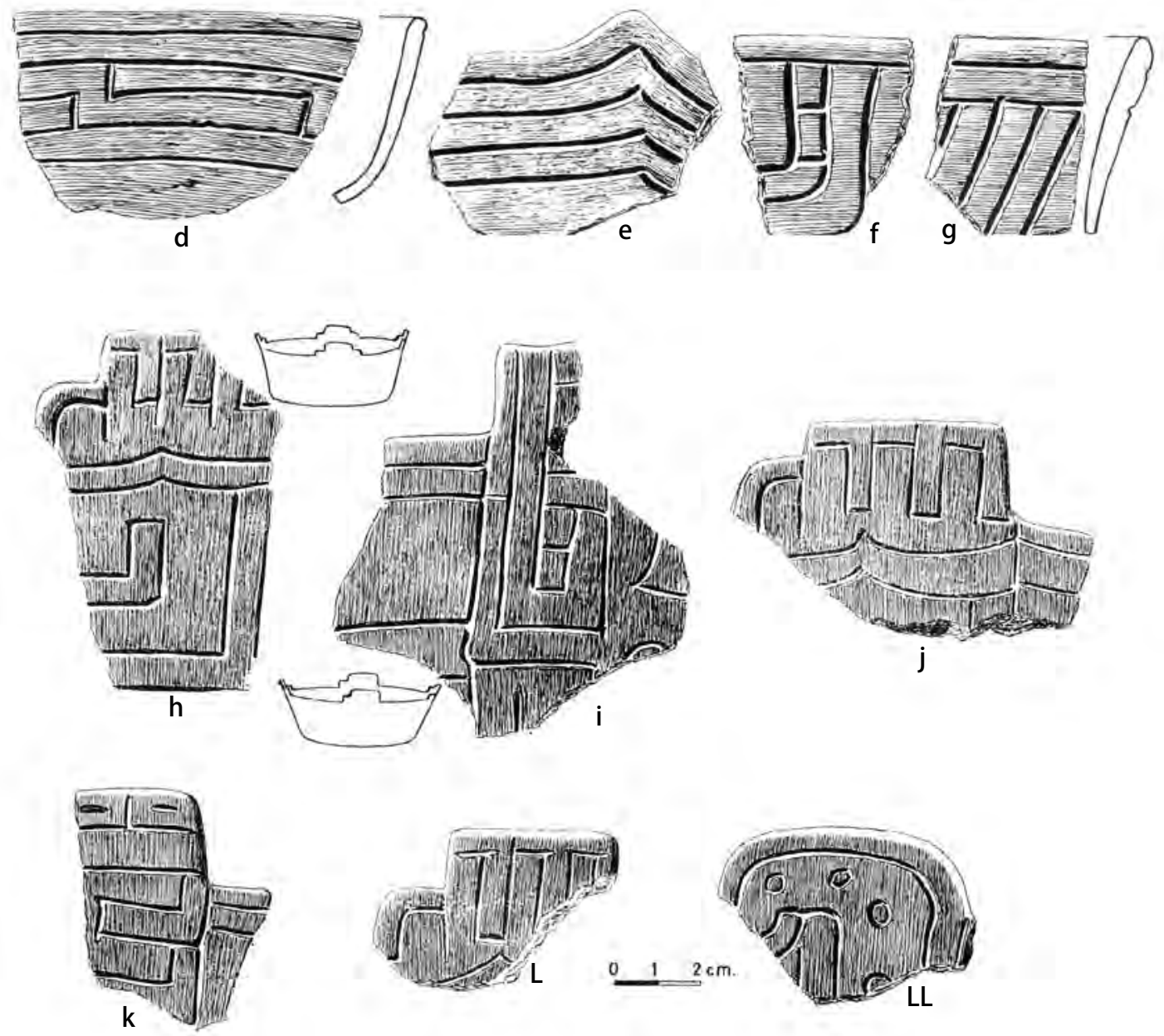

Figura 11. Cerámica de la Fase Pacopampa: Tipo inciso superficial. 
Motivo: Semejante al tipo inciso cortante.

\section{Pacompampa tiras sobrepuestas (Fig. 12)}

Pasta

Manufactura: Enrollada.

Temperante: Partículas blanquecinas con intrusiones rojas.

Textura: Distribución homogénea, deleznable, fractura irregular. Grosor: $26 \mathrm{~mm}$ a $50 \mathrm{~mm}$.

Color: Predominan los rojos o marrones sobre los grises.

Cocción: Reducida y mal oxidada.

\section{Superficie}

Color: Puede ser el exterior rojo o marrón con la superficie interna gris o la inversa.

Tratamiento: Superficie externa, de alisado tosco y pulido opaco a regularmente pulido; interior alisado o pulido opaco.

Dureza: 2.5, escala de March.

\section{Forma}

Sin mayor variación.

- Ollas de borde en coma, labio redondeado o biselado interiormente, lados inclinados hacia el interior, cuerpo esférico; espesor: 42 a $68 \mathrm{~mm}$.

- Bols de borde invertido, labio redondeado, lados gruesos hacia la boca con 75 a $90 \mathrm{~mm}$ de espesor, a diferencia de 35 a $40 \mathrm{~mm}$ en el cuerpo.

\section{Decoración}

Técnica: Delgadas cintas de arcilla aplicadas sobre el cuerpo de las vasijas, luego presionadas con el dedo o un instrumento de punta roma, en forma uniforme. Las vasijas abiertas tienen una banda pintada de rojo pre-cocción debajo de la superficie externa del labio.
Motivo: Cordoncillos y lóbulos o simples pastillas circulares de $76 \mathrm{~mm}$ con orificio central.

Otros: Escasos tiestos incluyen las siguientes técnicas decorativas.

\section{Pacopampa Peinado}

\section{Pasta}

Manufactura: Enrollada.

Temperante: Granulado, blanco abundante.

Textura: Distribución homogénea, 47 a 59 mm de grosor.

Color: Marrón.

Cocción: Oxidada.

\section{Superficie}

Color: Rojo y marrón.

Tratamiento: Pulido tosco en la superficie externa, regularmente pulido en el interior;

Dureza: 2.5 en la escala de March.

\section{Forma}

- Bols de borde directo, labio redondeado o plano, lados divergentes.

\section{Decoración}

Técnica: Peinado irregular sobre la superficie externa.

Motivos: Haces o bandas verticales paralelas; otros forman triángulos o círculos.

Exciso: Rellenado con pintura roja postcocción; punteado oval en zonas delimitadas por incisiones cortantes. Rara es la presencia de un bol con reborde o "pestaña" inciso, aplicado a 
pocos centímetros debajo del labio; además se encuentran cuatro tiestos que representan figuras modeladas, brazos, pies y cabeza de ave.

\section{Pacopampa - Chavín}

Después de la fase Pacopampa, la cultura Chavín alcanza amplia distribución. Se la encuentra en los estratos superiores, último en las excavaciones que no evidencian superposición de la cultura Cajamarca y segundo en los sitios ocupados por esta cultura.

Estratigráficamente difiere en naturaleza y color de los niveles precedentes. En el pozo 1B se encontró un estrato de $60 \mathrm{~cm}$ de tierra estéril en materiales arqueológicos, antes de la presencia de Chavín, e igualmente un lente delgado a lo largo de $3.50 \mathrm{~m}$ en el pozo 1, no así en las excavaciones restantes; sin embargo, el primero está dentro del área removida para la construcción de una galería y posiblemente fue alterado.

Debido a que realizamos las excavaciones por niveles naturales, no hemos podido separar unidades cortas, que es probable tengan significado temporal. Es por esto que incluimos momentáneamente dentro de una fase hasta tres estilos distintos.

Los tipos Pacopampa Pulido estriado, Negro inciso, Gris pulido, Rojo grafitado, etc., tienen semejanza con la cerámica Kotosh y Rocas; en cambio los tipos Modelado cintado, línea bruñida y Acordonado, que parecen ser temporalmente anteriores a Chavín, están ausentes en los dos sitios al igual que los tipos Rojo inciso fino, Bandas rojas, algo más tardíos, y en algunas excavaciones, asociados a las primeras fases Cajamarca.

Si bien es cierto, la presencia de cerámica chavinoide está asociada con nuevas técnicas de fabricación, mejor acabado y técnica decorativa, hay motivos y formas tradicionales que persisten tales como las representaciones felínicas, los diseños circulares, pero estampados, las formas escalonadas, lobuladas o dentadas de los bols y tazas, en nuevas combinaciones y mayor variedad de presentación.
Abstrayendo los rasgos generales de esta fase, tenemos: Manufactura enrollada o modelada, pasta fina casi compacta con antiplástico constituido de partículas negras e intrusiones de mica. Tratamiento de la superficie muy bueno, de preferencia en el exterior; predominio de las vasijas abiertas, labio biselado o redondeado, base aplanada, aunque hay considerable aumento de cántaros de cuello corto, en menor cantidad con gollete estribo y labio biselado, en relación a la fase anterior; la cocción sigue teniendo deficiencia pero ha mejorado notablemente; los motivos decorativos son variados realizados con técnica muy elaborada, las incisiones son anchas y profundas, trazo regular, cama pulida, escasos con grafito o pintura roja post-cocción; pocos son los diseños en relieve y la decoración interna con representaciones de serpientes ofelinos, rara vez se decoró la base.

En la clasificación de la cerámica hemos seguido los mismos criterios anteriores. Los nombres de estos tipos y aquellos son puramente convencionales.

\section{Pacopampa Acordonado (Fig. 13)}

\section{Pasta}

Manufactura: Enrollada.

Temperante: Granulado, mixto con predominio de partículas blancas, opacas, negras, de tamaño grande e intrusiones de mica.

- Blanquecino menudo con ingredientes rojizos, semejante a la fase Pacopampa.

- Gránulos rocosos, color mostaza, abundante.

Textura: En los dos primeros casos, antiplástico abundante, distribución uniforme, regularmente compacta, sin bolsas de aire; en el último, la mezcla es desigual, aunque numeroso, en algunos sectores hay mayor concentración.

Color: La mayoría tiene los extremos beige y gruesa franja central gris claro o gris oscuro. 

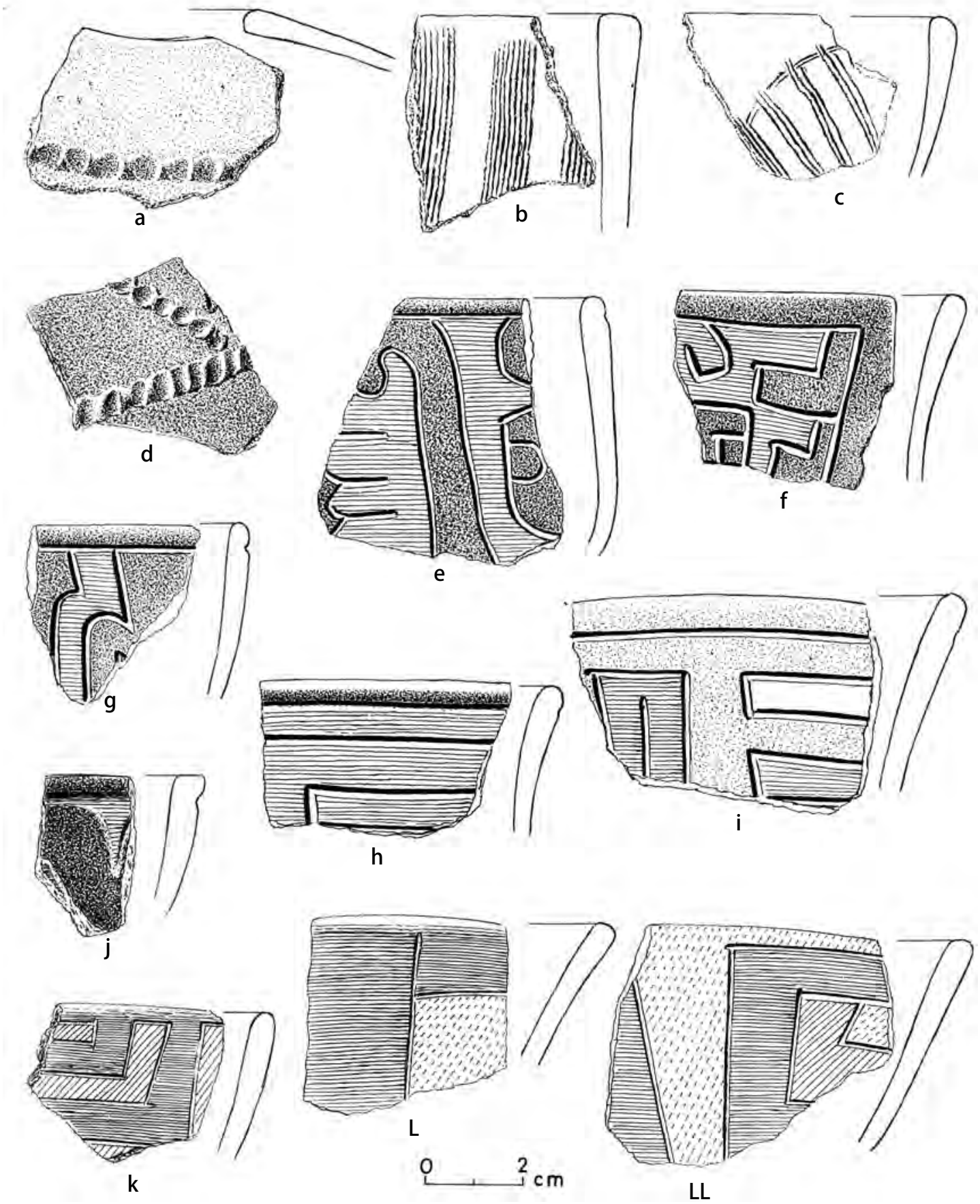

Figura 12. Cerámica de la Fase Pacopampa: Tiras sobrepuestas (a, d); peinado (b, c); pintado post-cocción (e-h); pintado policromo $(i, k, l l)$. 


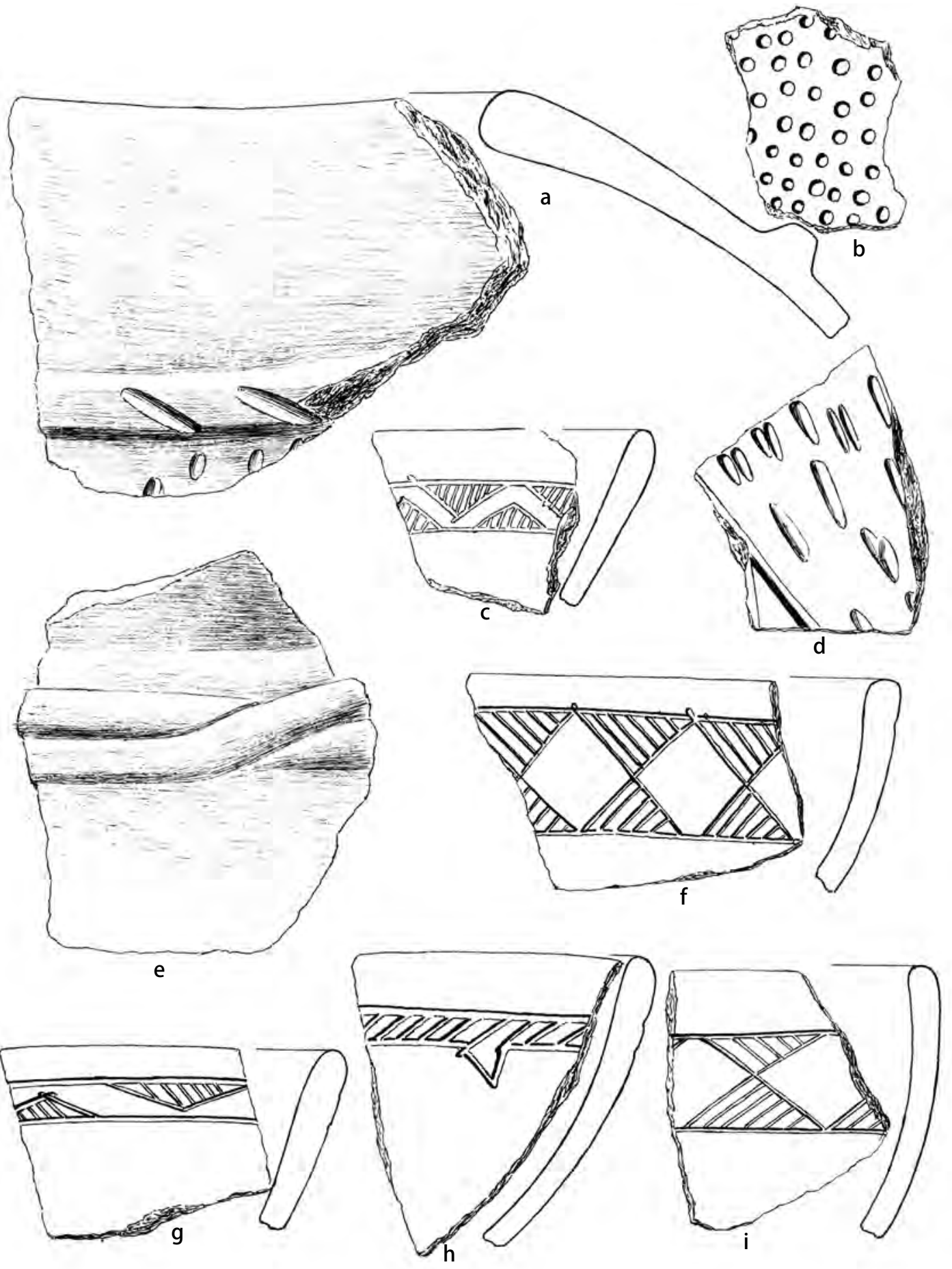

Figura 13. Cerámica de la Fase Pacopampa-Chavín: Tipo Acordonado (a-b, d-e); tipo Rojo inciso fino (c, f-i). 
Cocción: Mala oxidación, debido posiblemente al grosor de la pasta.

\section{Superficie}

Color: Exterior rojo, interior rojo o gris.

- Ambas superficies beige con manchas grises.

Tratamiento: Puede ser pulido opaco, pulido regular con huellas horizontales del instrumento empleado, o alisado tosco. Frecuentemente es visible el temperante.

Dureza: 2 a 2.5, escala de March.

\section{Forma}

- Ollas, borde en coma, labio redondeado, engrosado interiormente, cuerpo esférico achatado hacia la boca, base probablemente convexa. Espesor, hacia los bordes: $90 \mathrm{~mm} 110 \mathrm{~mm}$; lados: $53 \mathrm{~mm}$ a $58 \mathrm{~mm}$.

- Bols de borde ligeramente curvado hacia el interior, labio redondeado o con reborde externo cintado, lados paralelos invertidos hacia la boca. Espesor: $75 \mathrm{~mm}$ a $90 \mathrm{~mm}$.

\section{Decoración}

Técnica: Cordones de arcilla aplicados sobre la superficie exterior de las vasijas, circundando la parte media del borde. Los cordones están incididos profundamente en diagonal, dejando espacios más o menos regulares. En el área inferior se han ejecutado incisiones ovales y redondas; otros llevan cordones simples y dobles.

\section{Pacopampa-Chavín bandas rojas}

\section{Pasta}

Manufactura: Enrollada.

Temperante: Blanco muy fino con intrusiones rojas, probablemente mezcla de material orgánico porque tiene poco peso, y numerosos orificios de tamaño diverso en la superficie.
Textura: Muy bien mezclado el antiplástico; distribución homogénea.

Color: Rojo, algunos con delgadas franjas grises en el centro.

Cocción: Regularmente oxidada.

\section{Superficie}

Color: Interior rojizo uniforme; exterior rojo con amplias manchas grises.

Tratamiento: Superficie interna pulido opaco; exterior muy irregular producto del alisado tosco, con huellas del instrumento empleado.

Dureza: 2, escala de March.

\section{Forma}

- Plato grande, borde ligeramente invertido, labio redondo, trazo irregular, lados curvados, base convexa. Espesor: $52 \mathrm{~mm}$ a $54 \mathrm{~mm} ; 86 \mathrm{~mm}$ a $74 \mathrm{~mm}$ en la boca.

\section{Decoración}

- Bandas anchas (150 a $180 \mathrm{~mm}$ ), pintadas de color rojo, en dirección diagonal, vertical u ondulada, sobre la superficie interna de color natural.

\section{Pacopampa-Chavín gris pulido (Figs. 14-16)}

\section{Pasta}

Manufactura: Enrollada.

Temperante: de dos clases.

- Negrogranulado de mezcla irregular,

- Blanco, fino abundante.

Textura: Compacta y de distribución uniforme, excepto en los que llevan desgrasante del primer tipo. Espesor: 25 a $65 \mathrm{~mm}$.

Color: Rojo con el centro gris, marrón y gris. 

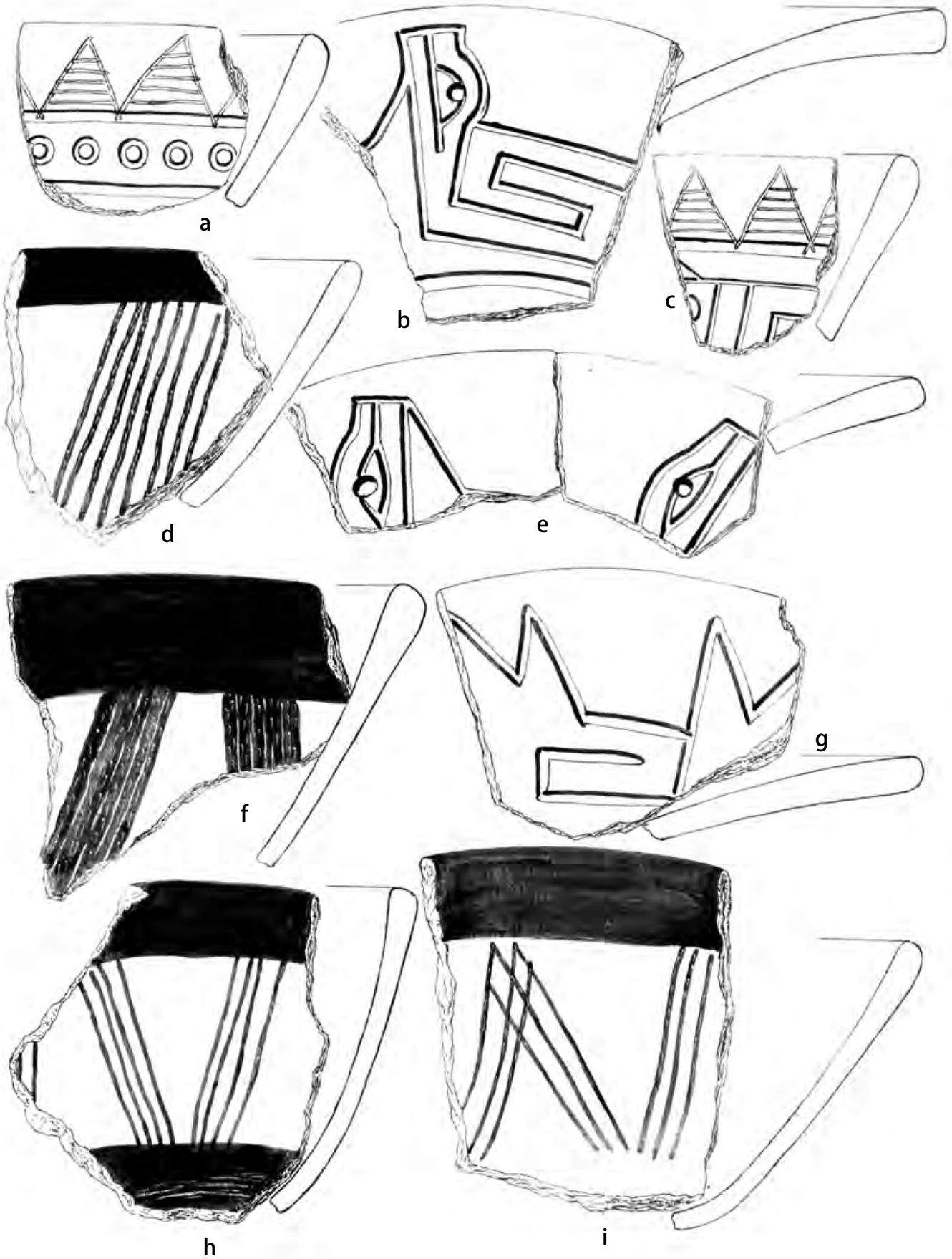

Figura 14. Cerámica de la Fase Pacopampa-Chavín: Tipo Gris pulido (a, c); tipo Negro inciso (b-e, g); tipo Línea bruñida (f-i). 

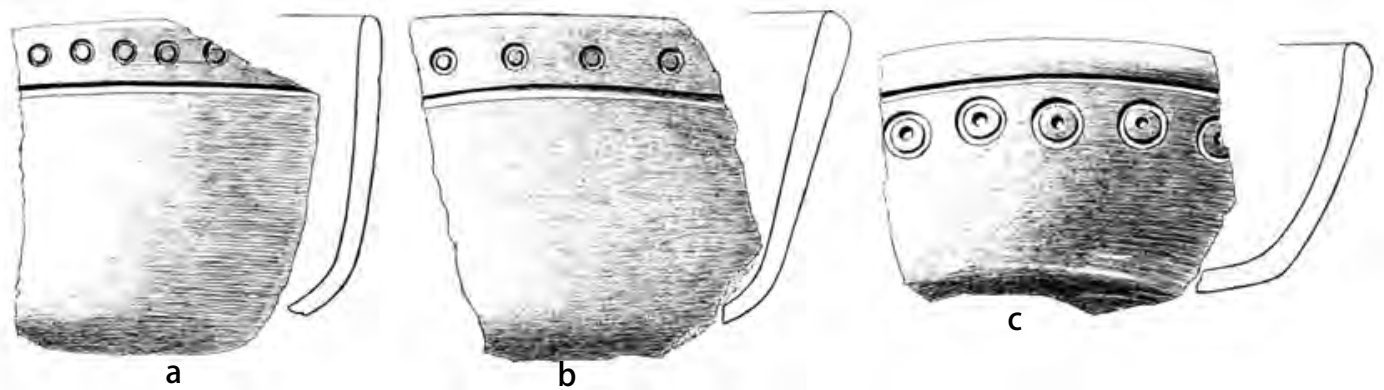

a
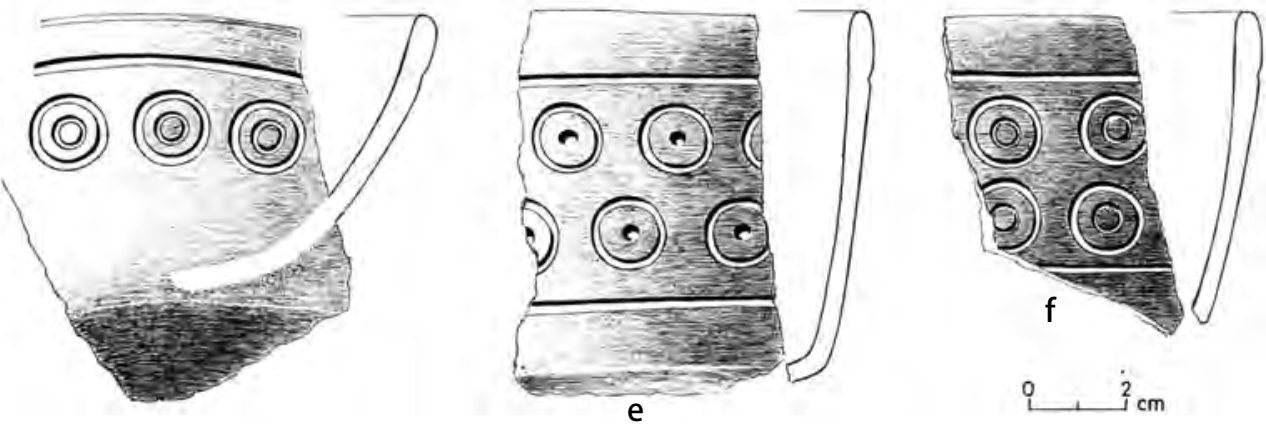

d
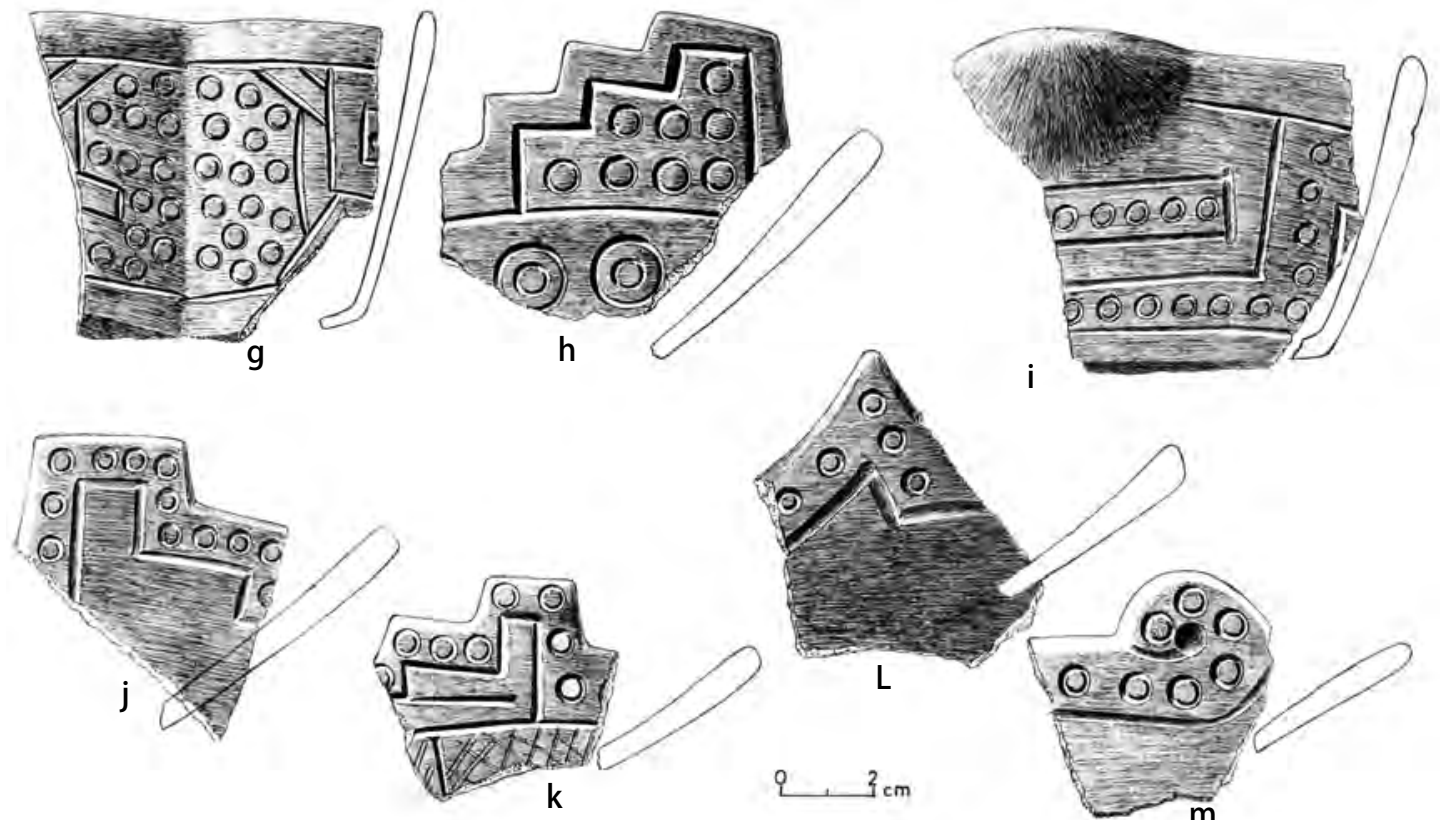

Figura 15. Cerámica de la Fase Pacopampa-Chavín. Tipo gris pulido. 

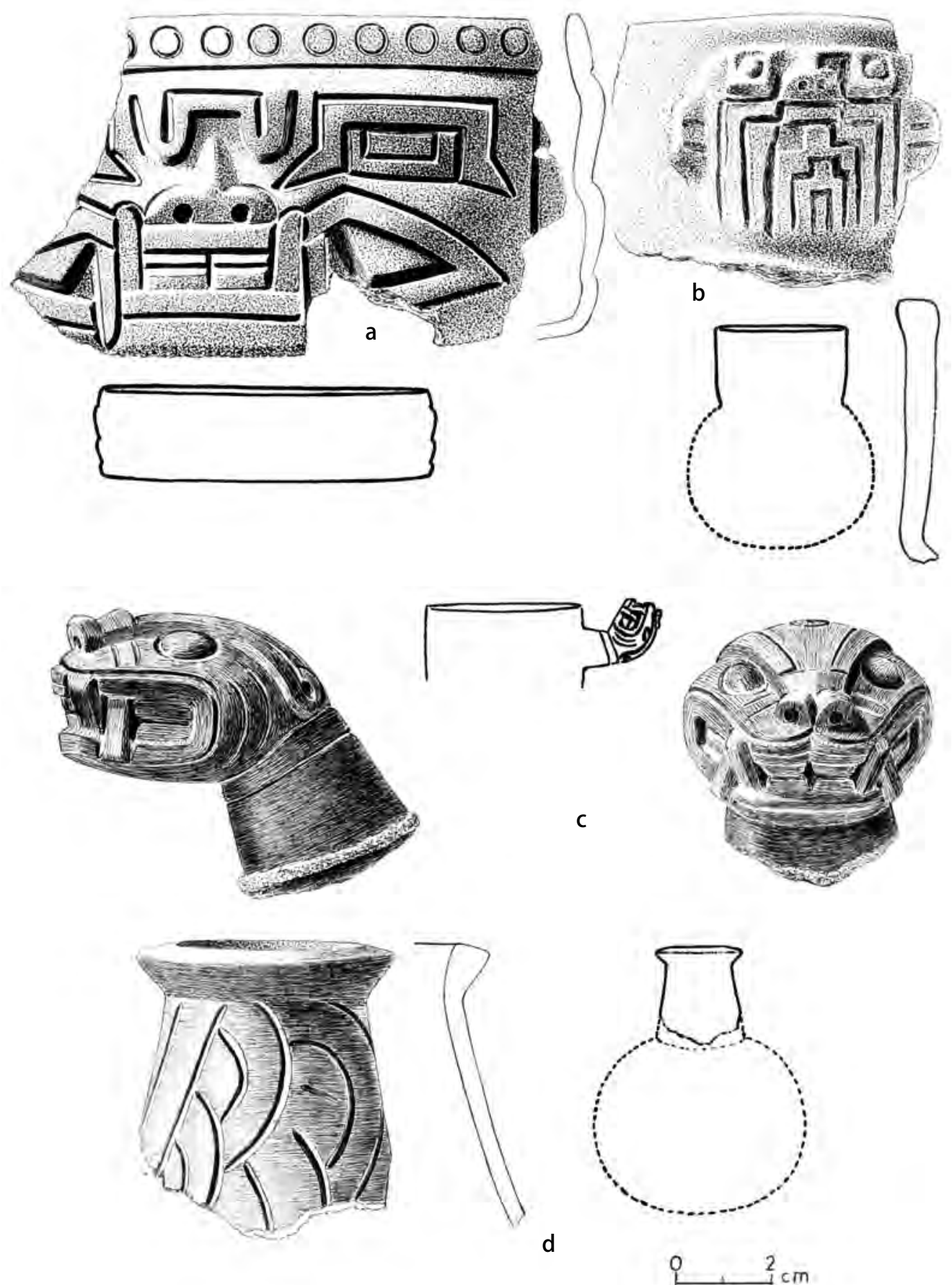

Figura 16. Cerámica de la Fase Pacopampa-Chavín. Tipo gris pulido. 
Cocción: Regularmente oxidada, algunos llegan a tener color rojo brillante, uniforme; escasos reducidos.

\section{Superficie}

Color: La superficie externa varía de un gris claro a oscuro; el interior puede ser del mismo color o ligeramente rojizo. En menor cantidad aquellos de superficie marrón o roja.

Tratamiento: Bien pulido, de preferencia el exterior que pude ser bruñido. Algunos llevan una capa de engobe rojo, en especial los bols y cuellos de cántaros.

Dureza: 2.5 a 3, escala de March.

Formas: Predominan las vasijas abiertas en un $85 \%$.

Vasijas cerradas:

- Jarras de cuello corto $(3.45 \mathrm{~cm})$, borde directo, labio redondeado, cuerpo esférico, base probablemente convexa.

- Ollas, borde en coma, labio plano o con bisel externo, lados curvos, base redondeada.

Vasijas abiertas:

- Platos, borde directo, labio biselado o redondeado, engrosado interiormente, lados divergentes, base con tendencia al plano. Diámetro de base: 27 a $32 \mathrm{~cm}$.

- Bols, borde expandido, labio biselado o redondo, lados de grosor uniforme, ligeramente expandidos hacia la boca, base aplanada. Grosor: 35 a $50 \mathrm{~mm}$. Diámetro de boca: 14 a $18 \mathrm{~cm}$.

- Bols, borde directo, labio redondeado, lados ligeramente verticales, base aplanada; diámetro de boca: 22 a $25 \mathrm{~cm}$.

- Platos, borde inclinado exteriormente, labio redondeado o plano. Grosor: $23 \mathrm{~mm}$ a $35 \mathrm{~mm}$.

- Bols, borde directo, labio de contorno almenado, lobulado, aquillado, angular o con vertedera, base aplanada.

- Bols de lados verticales cortos, predomina el diámetro a la altura, labio redondo, silueta irre- gular debido a la ejecución de figuras modeladas en el exterior, base plana.

- Fragmentos de gollete, probablemente estribo, lado biselado. Grosor: 23 a 35 mm.

- Fragmentos de asa cintada; ancho: $1.35 \mathrm{~cm}$ por $55 \mathrm{~mm}$ de espesor.

- Fragmentos de base anular.

\section{Decoración}

Técnica: Incisiones de trazo regular bien ejecutadas, cama pulida con $26 \mathrm{~mm}$ de ancho y 14 $\mathrm{mm}$ de profundidad, sobre superficie externa muy pulida. Algunos tiestos llevan decoración bruñida en el interior. En las vasijas de labio almenado o lobulado, los diseños siguen su contorno.

\section{Motivo: Variado}

- Sucesión de círculos estampados encima del borde, limitados en el extremo inferior por una línea incisa ancha.

- Círculos estampados en el interior de una banda horizontal, en otros casos puede reemplazar los círculos con punto o combinarse círculos estampados con círculos simples.

- Combinación de bandas horizontales con círculos estampados o simples; encima del borde triángulos de trazo irregular cubierto con líneas horizontales o diagonales, hechas cuando la arcilla estaba seca.

- Bandas verticales intercaladas con horizontales y oblicuas, cubiertas con círculos estampados o simples.

- Círculos con puntos y una mano en relieve aplicada encima del borde.

- Círculos estampados dobles.

- Círculos estampados con puntos.

- Bandas rectas o grecas cubiertas interiormente con puntos redondos, ovales, oblongados.

- Área en relieve y otras rebajadas.

\section{Pacopampa Línea bruñida (Fig. 14)}

\section{Pasta}

Manufactura: Enrollada. 
Temperante: Dos clases:

- Blanquecino fino, bien mezclado.

- Negro granulado, mezcla irregular. Mayor frecuencia.

Textura: Compacta y uniforme en los tiestos de temperante blanquecino; estructura irregular en los negros. Grosor: 42 a $51 \mathrm{~mm}$.

Color: Rojizo a marrón y gris.

Cocción: Oxidada regular, algunos reflejan mal control del fuego; escasos en atmósfera reducida.

\section{Superficie}

Color: Va de gris oscuro a gris claro, algunos con manchas rojizas y de rojo a marrón en una oen ambas superficies. Algunos tiestos muestran engobe rojo en el interior; el exterior es gris oscuro.

Tratamiento: Pulido opaco en el exterior, frecuentemente con huellas del pulidor; escasos con pulido más regular. En el interior hay áreas contrastantes de pulido opaco y bruñido.

Dureza: 2.5, escala de March.

\section{Forma}

Predominan las vasijas abiertas.

- Platos de borde directo, labio biselado exteriormente, lados divergentes, engrosados hacia la boca, base probablemente redondeado.

- Platos de borde inclinado interiormente, labio aplanado, lados curvados. Grosor: 45-52 $\mathrm{mm}$. Diámetro de boca: 18 a $22 \mathrm{~cm}$.

- Tazas de borde directo, labio redondeado o con bisel externo, lados ligeramente divergentes, espesor uniforme, 45 a $49 \mathrm{~mm}$, base probablemente convexa. Diámetro de boca: 16 a $17 \mathrm{~cm}$.

\section{Decoración}

Técnica: Líneas bruñidas, bien ejecutadas, sobre superficie interna pulida o alisada, dando aspecto de contraste. El labio, en general, está completamente bruñido, en las vasijas abiertas forma una franja en el interior $(2.30 \mathrm{~cm})$. Las vasijas cerradas llevan líneas bruñidas en la superficie externa.

\section{Motivo}

- Líneas bruñidas diagonales-paralelas, convergen a una ancha banda bruñida que bordea la boca de la vasija y siguen una dirección divergente hacia la base.

- Líneas verticales o diagonales que se entrecruzan formando rombos o triángulos.

- Simples líneas verticales.

Nota: Aunque tenemos 3 fragmentos de este tipo procedentes del corte 5-IV, lo ubicamos en esta fase por ausencia en los niveles subsiguientes y porque aparecen con mucha frecuencia en los últimos estratos.

\section{Pacopampa Llano}

\section{Pasta}

Manufactura: Enrollada.

Temperante: Predominan los tiestos de pasta gruesa con granos rocosos de color negro y mica sobre aquellos de partículas finas, blanquecinas.

Textura: Compacta, fractura irregular, granos de tamaño variado, distribución uniforme. Generalmente el desgrasante es visible en ambas superficies.

Color: Rojo o marrón con el núcleo negruzco, escasos grises.

Cocción: Son más frecuentes los tiestos oxidados, casi todos con defectos de cocción.

\section{Superficie}

Color: $80 \%$ de la muestra, rojos o marrones, muchos con manchas grises. Se nota una tendencia en este tipo hacia el color rojo, inclusive 
los que por cocción reducida obtenían la superficie gris eran engobados de ese color.

Tratamiento: Exterior regularmente pulido, pulido opaco o alisado en el interior de las vasijas cerradas; de regular a buen pulido en las abiertas. Un gran sector lleva engobe rojo.

Dureza: 3 a 3.5, escala de March.

\section{Forma}

- Platos, borde directo, labio generalmente redondeado, escasos biselados y con reborde exterior, lados divergentes, engrosados hacia la boca, base convexa. Espesor: 57 a $65 \mathrm{~mm}$.

- Platos, borde invertido, labio redondeado y biselado, lados curvados, algunos engrosados hacia la boca, base convexa. Espesor: 48-55 a 66$105 \mathrm{~mm}$ en el labio.

- Borde casi vertical, labio engrosado exteriormente, redondeado o biselado. Espesor 52 a 65 y 98 a $132 \mathrm{~mm}$ en la boca. Probablemente corresponde a bols.

Vasijas cerradas:

- Jarras de cuello largo, borde vertical, labio engrosado exteriormente, redondeado, plano o con bisel lateral, cuerpo probablemente globular. Espesor del cuello: 55-65 a 98-150 mm en la boca.

- Jarras, cuello corto, borde expandido, labio generalmente redondeado, algunos con pequeño bisel lateral o central, cuerpo globular. Espesor: 40 a 68 y 68 a $82 \mathrm{~mm}$ en la boca.

- Ollas, en número escaso, borde en coma, labio redondo o con bisel central, algunos engrosados hacia la boca, cuerpo esférico, base convexa. Espesor: 35 a $65 \mathrm{~mm}$ y 72 a $130 \mathrm{~mm}$ en la boca.

Pacopampa - Chavín modelado cintado (Figs. 17-19)

\section{Pasta}

Manufactura: Modelada, simultánea con la aplicación de cintas de arcilla.
Temperante: Gránulos negros de tamaño grande con intrusiones de mica esparcidos en forma homogénea; escasos tienen partículas blancas.

Textura: Pasta gruesa y tosca pero compacta, sin bolsas de aire. Muy visible el antiplástico en la superficie.

Color: el 95\% rojo con extensa franja central de color gris.

Cocción: Oxidada. A pesar del grosor de la pasta se nota mejor control del fuego.

\section{Superficie}

Color: Varía de rojo a beige, algunos con manchas grises.

Tratamiento: Pulido opaco en el exterior con aplicaciones formando figuras diversas; interior alisado, pulido estriado o pulido opaco. Mayormente el borde exterior está engobado de rojo y bien pulido. Algunos tienen pintura roja postcocción en los canales que separan las figuras en relieve.

\section{Forma}

Contamos con numerosos tiestos de cuerpo y escasos bordes que dificultan la reconstrucción. Las características son: borde directo, labio con reborde externo, boca de grandes dimensiones $(45$ a $50 \mathrm{~cm})$, lados paralelos con tendencia a expandirse ligeramente hacia el borde. Algunos tienen labio con bisel interno. Espesor: 89 a 174 $\mathrm{mm}$.

- Jarras, cuello de 8 a $10 \mathrm{~cm}$, llevan los mismos diseños que los anteriores en uno de los lados del cuello; otros tienen la figura modelada en la parte media superior del cuerpo.

\section{Decoración}

Técnica: Aplicación de cintas de arcilla al mismo tiempo que se modelaban las figuras. Canales amplios e incisiones anchas, o angostas 

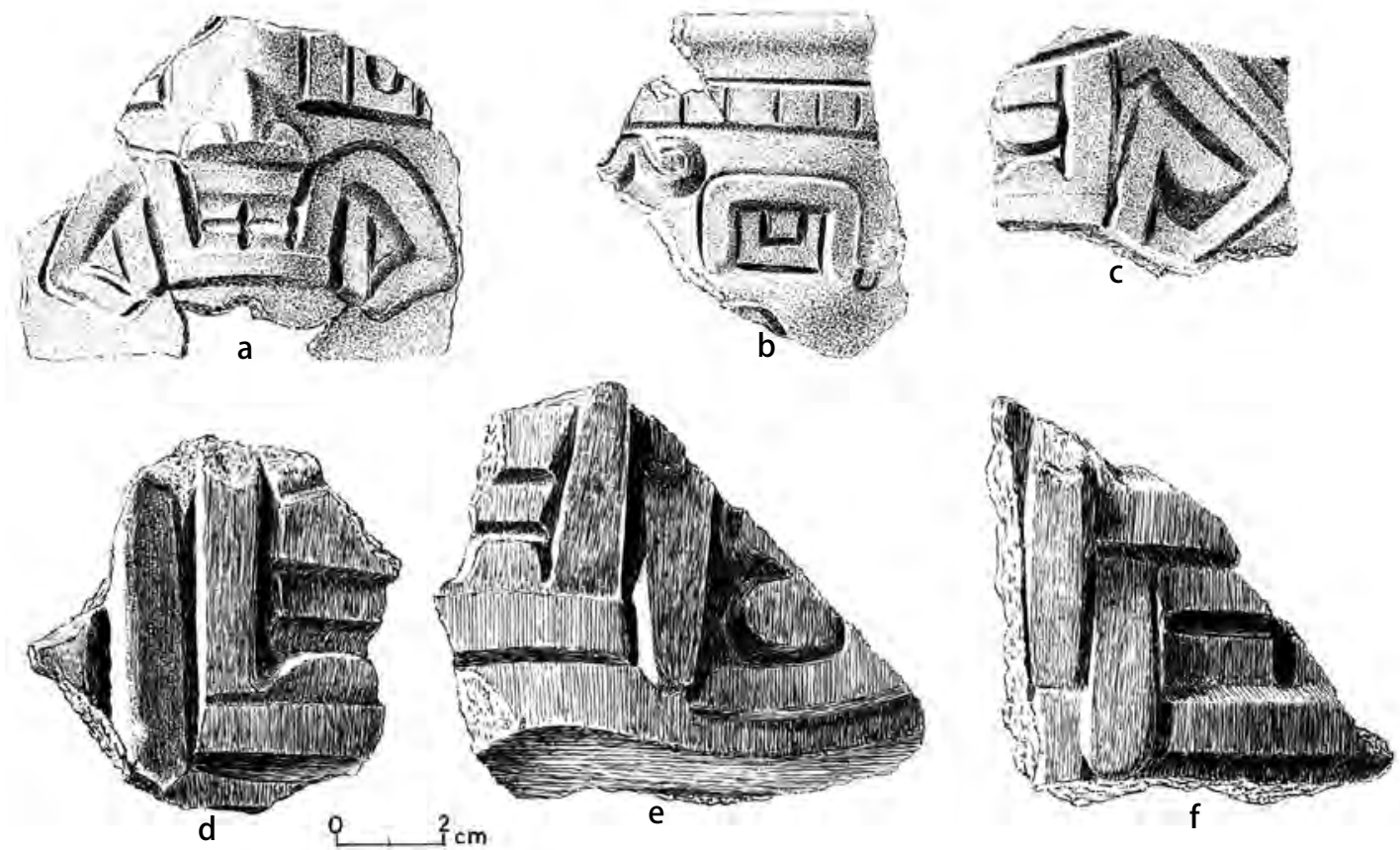

Figura 17. Cerámica de la Fase Pacopampa-Chavín. Tipo cintado modelado cintado.

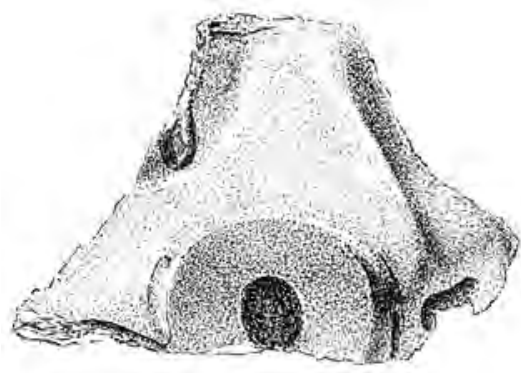

a

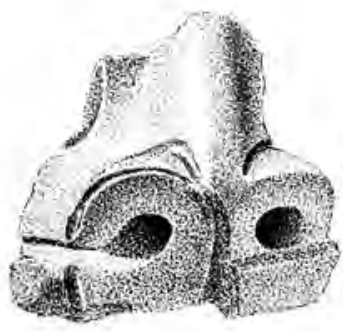

b
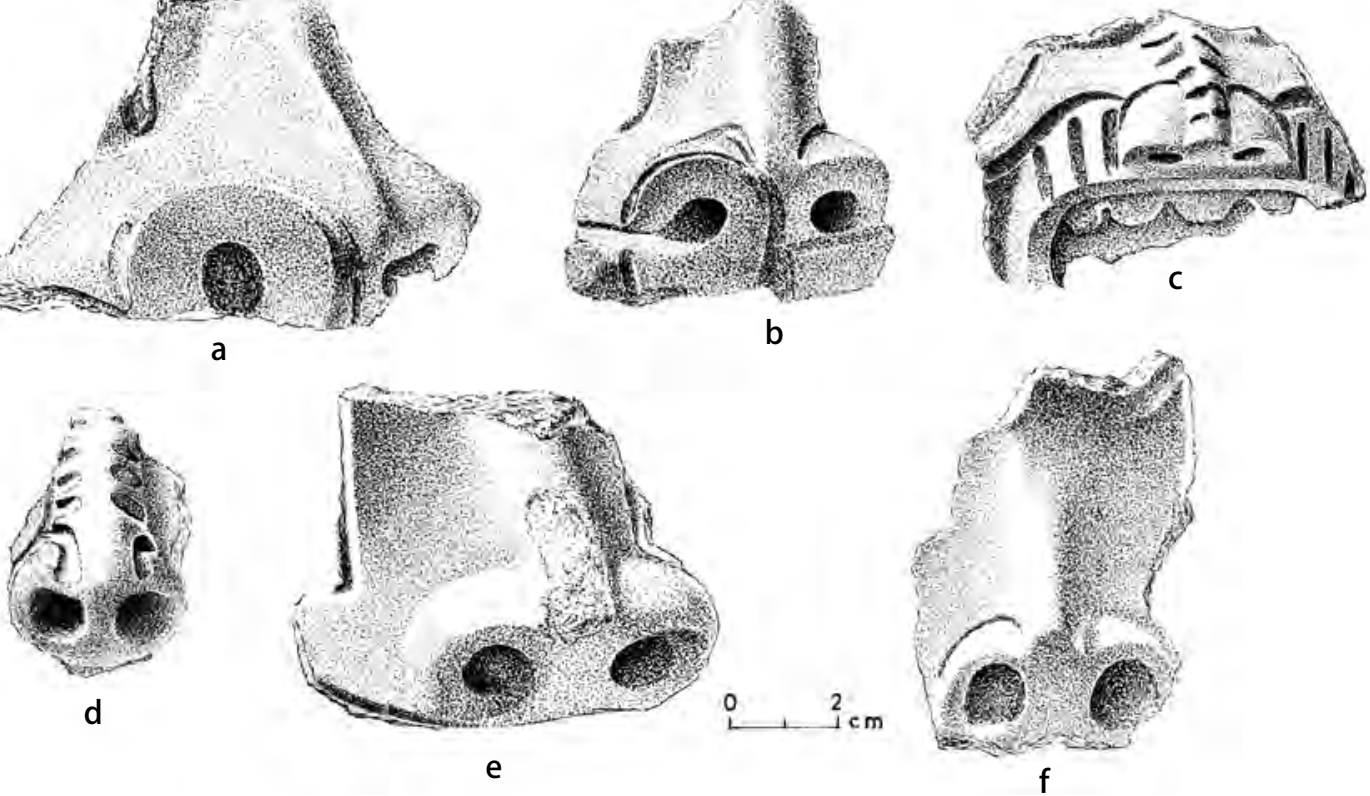

Figura 18. Cerámica de la Fase Pacopampa-Chavín. Tipo modelado cintado. 


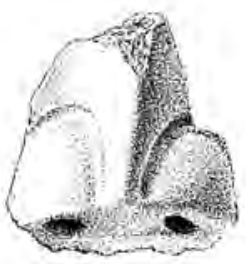

a
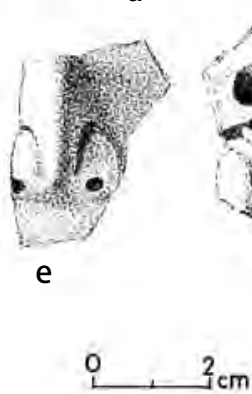

$2 \mathrm{em}$

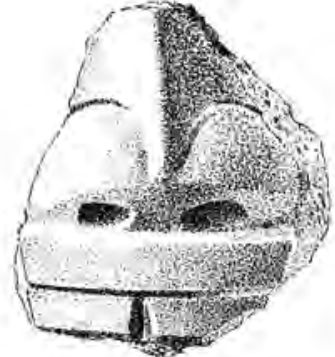

b
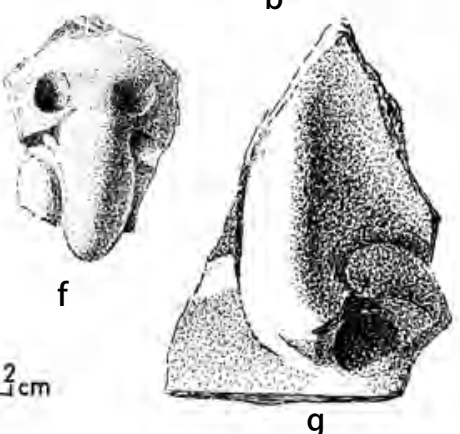

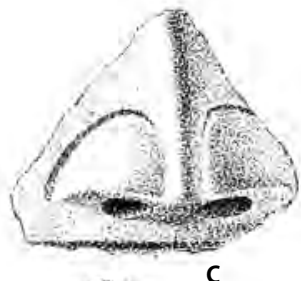

C
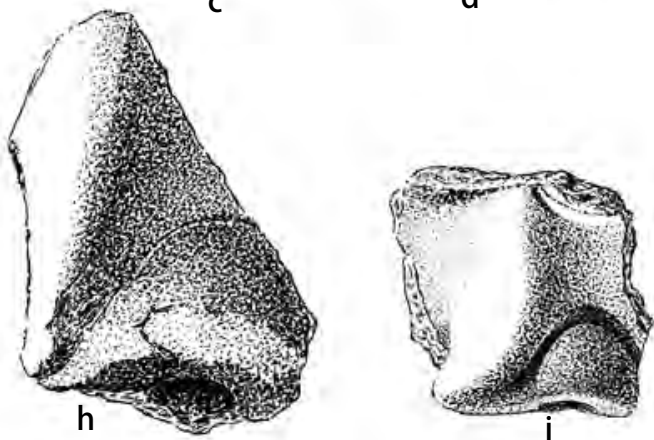

Figura 19. Cerámica de la Fase Pacopampa. Tipo modelado cintado.

y profundas, separan los diseños o constituyen también parte de ellos. En conjunto, presenta contrastes de alto y bajo relieve. En escasos tiestos las aplicaciones han sido reemplazadas por incisiones anchas pero delineando los mismos motivos. En algunos, los canales o incisiones de separación llevan pintura roja post-cocción.

Motivos: El 90\% son figurativos, rostros con caracteres felínicos y humanos, cara de zorros y aves.

Características: Ofrecen gran variedad. Los ojos son rectangulares, enmarcados con amplias cejas, a base de cintas de arcilla en relieve de extremos acordados, tipo Sechín, pupilas excéntricas; la nariz adquiere diversas modalidad, perfil corvado con aletas dilatadas, fosas nasales simiescas; curvado a un lado o una fosa nasal muy resaltada que se conecta a la cinta que forma los labios; boca con grandes colmillos que ocupan casi toda la cavidad, las comisuras triangulares exageradas; orejas de forma humana, ornadas con orejeras circulares. En el extremo opuesto de ésta, una cabecita de serpiente.

Entre otras figuras se encuentra, cabecitas de Canchul (Muca) y loro, representados muy realísticamente. Diseños complementarios son generalmente cordones, bandas de círculos estampados con puntos centrales, puntos ovales, acompañan a las representaciones mayores.

\section{Pacopampa - Chavín negro inciso}

\section{Pasta}

Manufactura: Enrollada.

Temperante: Generalmente cuarzo con partículas blanquecinas; en menor número, granos negros e intrusiones de mica.

Textura: Fina, mezcla uniforme sin bolsa de aire.

Color: Rojo, marrón o gris, con mayor frecuencia de los primeros. 
Cocción: Mayormente oxidada, escasos con banda gris central; el cocimiento en atmósfera reductora también es uniforme.

\section{Superficie}

Color: Predomina el color gris en ambas caras, pocos son marrones. Carecen de manchas claras u oscuras.

Tratamiento: La superficie interna está mejor pulida, en algunos casi bruñida; en cambio, el exterior puede ser regularmente pulido o pulido tosco, con huellas del instrumento utilizado. En muchos se trasluce la mica en la cara externa.

\section{Forma}

- Bols, borde acentuadamente expandido, labio redondeado, lados constreñidos del ecuador hacia el borde, expandidos y curvados a la base, forma acampanada. Espesor: 60 a $90 \mathrm{~mm}$.

- Platos, borde directo, labio redondeado, lados muy divergentes, base probablemente convexa. Espesor: 60 a $90 \mathrm{~mm}$.

- Bols, borde directo, labio redondeado, lados casi rectos, ligeramente curvados hacia el interior en el borde, base posiblemente aplanada. Espesor: 42 a $50 \mathrm{~mm}$.

- Jarras de gollete cilíndrico, corto, asa plana, lateral.

- Fragmento de bols con labio almenado.

Dureza: 2.5 a 3, escala de March.

\section{Decoración}

Técnica: Incisiones anchas, trazo uniforme, cama limpia, pulida. Los diseños generalmente son ejecutados en la superficie interna, pocos en el exterior. Muchos llevan pigmento rojo postcocción en las incisiones.

Motivos: Pueden ser figurativos o geométricos.

- Serpientes con el cuerpo horizontal y la cabeza orientada hacia el borde.
- Representaciones de felinos a base de líneas rectas.

- Greca limitada en el inferior por incisión ancha. Ocupa el área interna superior del borde.

- Juego de líneas horizontales y verticales que posiblemente forman algún diseño mayor, asociadas a puntos y rayas incisas.

- Áreas en bajo y alto relieve con hiladas horizontales y verticales de círculos estampados. Diseño raro.

\section{Pacopampa Chavín pulido estriado}

\section{Pasta}

$$
\text { Manufactura: Enrollada. }
$$

Temperante: Granulado, negro con intrusiones de mica, escasos de partículas blancas finas.

Textura: Casi compacta, uniforme distribución del antiplástico.

Color: Predomina el rojo, en menor cantidad el color gris.

Cocción: Mayormente oxidada, aunque también reducida.

\section{Superficie}

Color: Exterior gris claro a oscuro, rojizo a marrón; interior puede ser rojo claro, gris oscuro o marrón.

Tratamiento: Pulido estriado, dejando huellas delgadas en diferentes direcciones sobre la superficie externa; el interior puede ser pulido, brochado o alisado tosco.

Dureza: 2.5, escala de March.

\section{Forma}

- Platos, borde expandido, labio redondeado, pronunciado hacia el exterior o con bisel interno, lados ligeramente curvados hacia la base. 
- Ollas, borde en coma, engrosado interiormente, labio redondo, cuerpo esférico. Espesor: 68 a $109 \mathrm{~mm}$.

- Jarras de cuello corto $(12 \mathrm{~cm})$, borde directo, labio engrosado exteriormente, cuerpo probablemente globular. Espesor: 60 a $48 \mathrm{~mm}$.

- Jarras de cuello corto (5 a $6.5 \mathrm{~cm})$, borde directo, labio engrosado hacia el exterior. Espesor: $70 \mathrm{~mm}$.

- Bols de boca amplia, borde ligeramente expandido, labio engrosado exteriormente, semejante a las jarras, lados casi rectos. Espesor: 65 a $90 \mathrm{~mm}$.

- Platos, borde directo o expandido, labio redondo biselado interno o aplanado, lados divergentes. Grosor: $110 \mathrm{~mm}$.

- Platos, borde directo, labio rebajado exteriormente, lados medianamente divergentes. Grosor: $68 \mathrm{~mm}$.

\section{Pacopampa-Chavín rojo grafitado}

\section{Pasta}

Manufactura: Enrollada.

Temperante: Predominan las partículas negras sobre las blancas, escasa mica.

Textura: Casi compacta, homogénea distribución del antiplástico.

Color: Muy variado, rojo y marrón, con mayor frecuencia del primero.

Cocción: Oxidada, algunos tienen el núcleo gris.

\section{Superficie}

Color: Rojo uniforme.

Tratamiento: Tanto la superficie interna como la externa están muy bien pulidas, alcanzando algunos el bruñido. Frecuente aplicación de engobe rojo en ambas caras y grafito en las incisiones.

\section{Forma}

- Bols, borde directo, ligeramente engrosado hacia la boca, labio rebajado exteriormente, lados casi divergentes curvados hacia la base, suavemente convexa. Espesor: 46-48 a 60-72 mm en la boca.

- Platos de borde invertido, labio redondeado, lados curvados, base probablemente convexa. Espesor: 47 a $60 \mathrm{~mm}$.

Dureza: Menos de 2 en la escala de March.

\section{Decoración}

Técnica: La decoración puede ir sobre la superficie externa o interna. Los diseños están hechos a base de incisiones anchas $(21-30 \mathrm{~mm})$, trazo irregular, cama pulida cubierta con grafito.

Motivo: Diseños escalonados descienden de una línea que circunda el borde.

- Línea única debajo del labio.

- Círculos estampados.

\section{Pacopamapa Chavín rojo inciso fino (Fig. 13)}

\section{Pasta}

Manufactura: Enrollada.

Temperante: Partículas blancas menudas, cuarzo e intrusiones rojas, muy semejante al antiplástico de los tipos de la Fase Pacopampa.

Textura: Uniforme dispersión del desgrasante, algo deleznable.

Color: El 90\% son rojos, los restantes marrones y grises.

Cocción: Oxidada, algunos con gruesa franja gris en el centro, pero se nota progreso en la cocción pues a pesar del grosor hay muchos completamente oxidados.

\section{Superficie}

Color: Superficie interna y externa roja, uniformada por engobe rojo claro o rojo indio. 
Tratamiento: Casi todos llevan engobe total o sólo en la superficie interna y exterior del borde, contrastando con el área de color natural.

Dureza: Entre 2 a 2.5 en la escala de March.

\section{Forma}

- Platos de borde directo, ligeramente engrosado hacia la boca, labio redondeado, lados curvados, base probablemente convexa. Espesor: 50 a $60 \mathrm{~mm}$ en la boca.

- Platos, borde directo, engrosado en la boca, labio redondeado, lados divergentes con tendencia a curvarse hacia la base que posiblemente es convexa. Espesor: 50 a $82 \mathrm{~mm}$ en la boca.

\section{Decoración}

Técnica: Incisiones delgadas y superficiales ejecutadas sobre la superficie externa cuando la arcilla estaba seca. Los diseños están restringidos al área debajo del labio, el cual está muy bien pulida. La superficie interna tiene pulido brillantes, raras veces con líneas bruñidas verticales y dirección horizontal en el borde.

Motivos: Pobreza de diseños.

- Bandas con triángulos dobles que se unen en los vértices en dirección vertical.

- Bandas que tienen triángulos cubiertos con líneas paralelas verticales o diagonales que se alternan, unas veces con el vértice arriba, la siguiente abajo.

\section{Artefactos de hueso (Fig. 20)}

\section{Pendiente}

Técnica: Tallado en relieve sobre la superficie externa de un trozo de hueso de camélido, previamente pulido.

Motivo: Figura de un personaje con caracteres felínicos, ojos rectangulares, pupila excéntrica, boca amplia con fisura romboidal, grandes colmillos, brazos y piernas recogidas, sugiriendo posición sentada. La cabeza ocupa más de la mitad del pendiente y se encuentra ornada con cabecitas de serpientes. (Fig. 20a)

Dimensiones: $4.5 \mathrm{~cm}$ de largo por $2 \mathrm{~cm}$ de diámetro y $58 \mathrm{~mm}$ de espesor.

Procedencia: Relleno del Muro B.

Nota: Figura semejante a las representaciones en el tipo cerámico modelado cintado (Fig. 17-19).

\section{Espátulas}

Técnica: Finamente elaboradas; algunas han sido adaptadas a las formas naturales del hueso, otras rebajadas hasta lograr láminas regulares. Algunos fueron pulidos en una sola cara, mientras que en la mayoría se pulió ambas superficies.

Forma: Algunas adquieren la forma de una cuchara con el mango también modelado (Fig. 20 ), y orificios en uno de los extremos.

Dimensiones: $8.74 \mathrm{~cm}$ de largo por $2 \mathrm{~cm}$ de ancho y $25 \mathrm{~mm}$ de espesor. Varía el tamaño del mango de 2.65 a $6.5 \mathrm{~cm}$.

Procedencia: Relleno de la Plaza Sagrada.

- Espátulas de contorno liso y aserrado con orificio circular en uno de los extremos. (Fig. 20)

Dimensiones: 5.85 a $11.5 \mathrm{~cm}$ de largo por 88 $\mathrm{mm}$ a $1.10 \mathrm{~cm}$ de ancho y 26 a $30 \mathrm{~mm}$ de espesor.

Procedencia: Relleno de la Plaza Sagrada.

\section{Punzones}

Técnica: Medianamente pulidos en material selecto. En algunos se ha aprovechado la forma natural del hueso como mango, dos están decorados. (Fig. 20)

Decoración: Incisiones delgadas, aplicadas sobre la superficie plana del mango, medianamente pulido. 

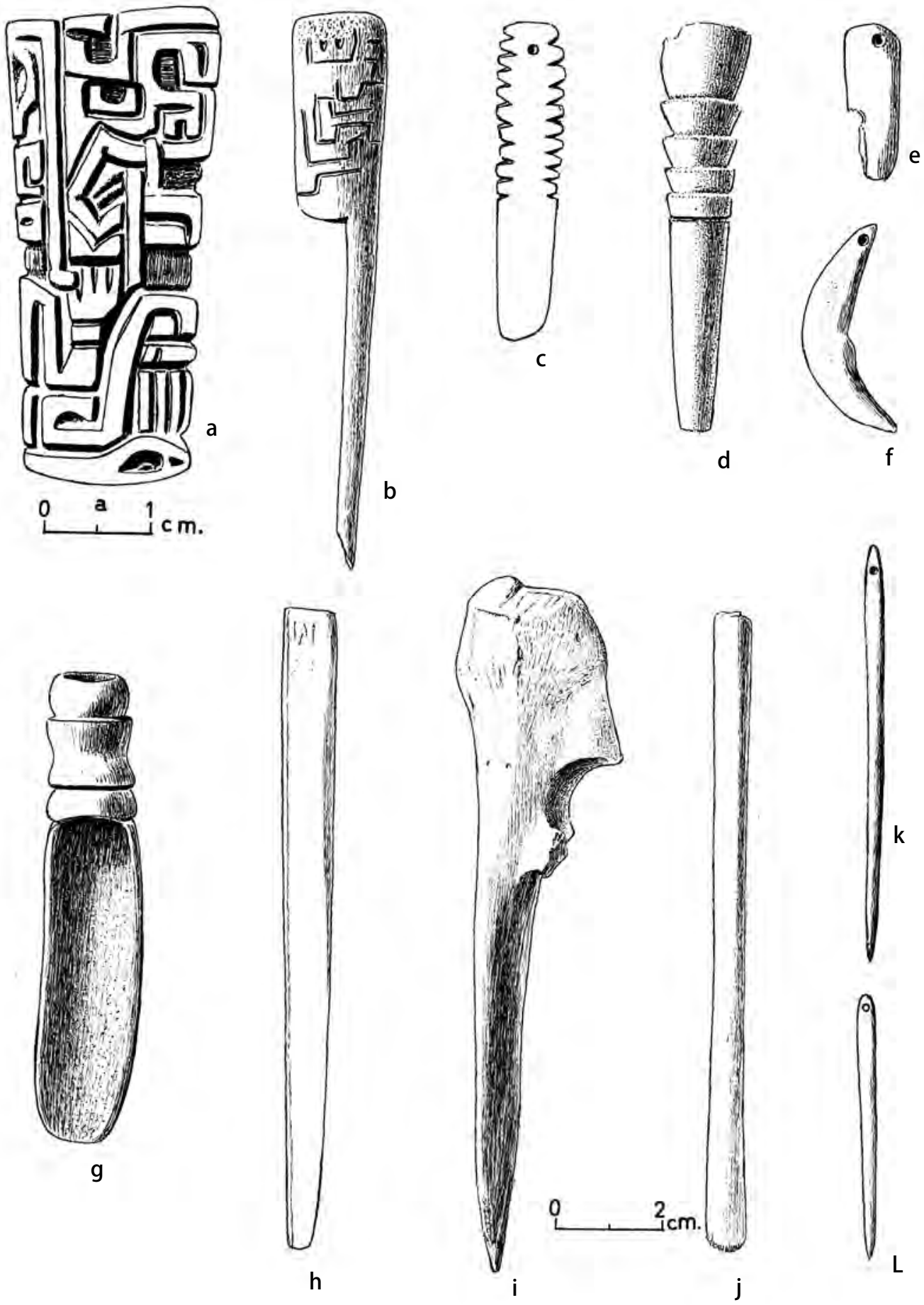

Figura 20. Osteodontoquerática, Fase Pacopampa-Chavín: Pendientes (a, e-f); espátulas (c-d, $g$-h); punzones $(b, i)$; agujas $(k-l)$. 
Motivo: Geométrico.

Dimensiones: 10.5 a $12.76 \mathrm{~cm}$ de largo por $1.60 \mathrm{a} 2.73 \mathrm{~cm}$ de ancho y 20 a $42 \mathrm{~mm}$ de espesor. Procedencia: Relleno de la Plaza Sagrada.

\section{Agujas}

Sólidas, finamente pulidas con punta aguda y orificio circular en el extremo opuesto. (Fig. 20kl).

Dimensiones: 5.5 a $7.8 \mathrm{~cm}$ de largo; 25 a 30 mm de diámetro.
Procedencia: Relleno, Plaza Sagrada.

Otros

- Pendientes elaborados en dientes de carnívoros, perforados. (Fig. 20e-f)

- Fragmentos óseos de trabajo inconcluso.

\section{Misceláneos (Fig. 21)}

1. Estatuilla humana tallada en piedra de grano fino, color beige. La figura adopta la forma de un personaje en posición erecta, con los pies juntos, los brazos flexionados pegados al cuerpo,

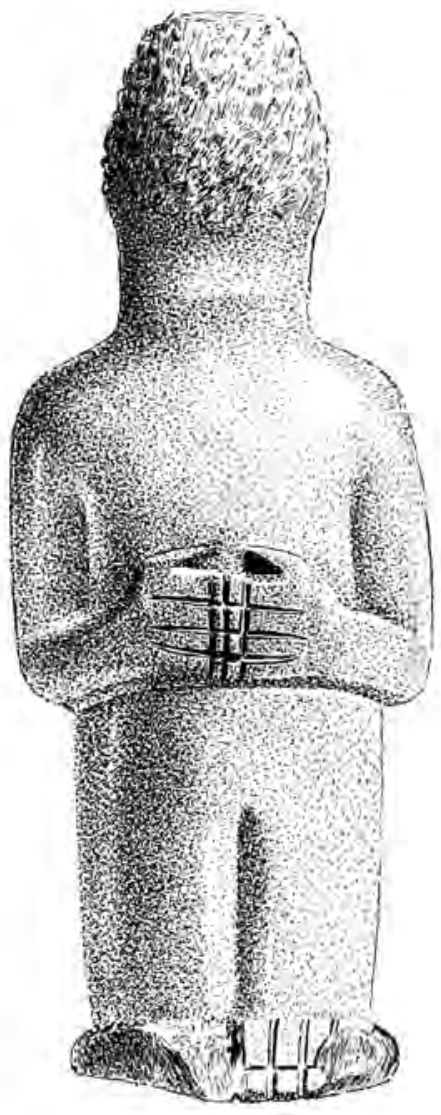

a
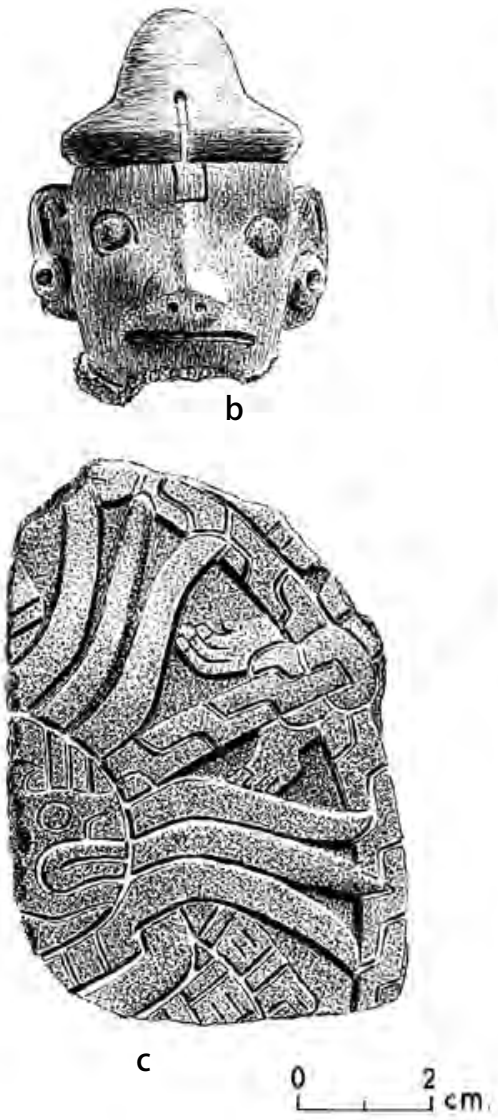
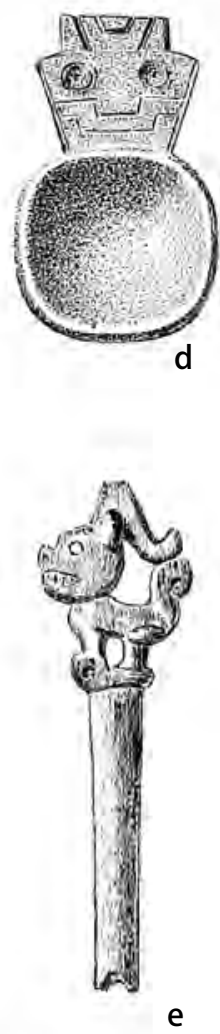

e

Figura 21. Lítico, cerámica y metal: Fase Pacopampa-Chavín: Estatuilla de piedra (a); cabeza humana modelada en arcilla (b); fragmento de bol o plato de piedra (c); cuchara de piedra (d); alfiler de cobre (e). 
con las manos y dedos unidos a la altura del abdomen. La cabeza fue dejada inconclusa. La parte posterior del cuerpo se encuentra dividida por una línea incisa vertical (Fig. 21a).

Dimensiones: $16 \mathrm{~cm}$ de alto por $6.33 \mathrm{~cm}$ de ancho, a la altura de los miembros superiores.

Procedencia: Desconocida, entregada por un habitante del lugar.

2. Cabeza de figura humana, modelada en arcilla y pintada de rojo. Sus características son: ojos redondos en relieve, nariz perfilada de aletas dilatadas, largas orejas con orejeras tubulares, boca grande señalada por incisión, tocado en forma de gorro. Parecidas a las figurinas de Kuntur Wasi. (Fig. 21b)

Dimensiones: $6 \mathrm{~cm}$ de alto por $4.43 \mathrm{~cm}$ de diámetro.

Procedencia: Relleno, Muro B.

3. Cuchara de piedra hecha en material similar a la estatuilla. Muy bien pulida, de mango incompleto, decorado. (Fig. 21d)

Decoración: Cara felínica, diseñada a base de líneas incisas.

Dimensiones: $5 \mathrm{~cm}$ de largo por $3 \mathrm{~cm}$ de ancho y $1.40 \mathrm{~cm}$ de profundidad. El mango tiene 2.40 $\mathrm{cm}$ de ancho y $58 \mathrm{~mm}$ de espesor.

Procedencia: Desconocida, encontrada en poder de un poblador de Tuca.

Nota: Por el estilo de la figura, se puede relacionar con la cara felínica representada en el tipo cerámico Inciso cortante, Fase Pacopampa. (Fig. $9 \mathrm{~m})$

4. Fragmento de taza o plato, elaborado en piedra rojiza, de grano fino, muy dura. La base exterior fue decorada con figuras en relieve sobre superficie previamente pulida.

Motivo: Algo impreciso debido a su mutilación. Se observa: cabeza de felino encerrada en lo que parece un círculo pequeño con apéndices en forma radial que llegan hasta un círculo mayor, formado por una banda decorada con grecas. De esta banda salen dos manos y otra franja menor que conecta con el círculo pequeño (Fig 21c).

Procedencia: Desconocida, recuperada.

5. Fragmento de aguja de cobre, con un felino pequeño en uno de sus extremos. De la cabeza sale un apéndice que se une al caudal. (Fig 21e).

Procedencia: Desconocida, recuperada.

\section{Discusión}

La región donde se ubica Pacopampa ofrece condiciones favorables para el establecimiento humano permanente. Su topografía está caracterizada por la presencia de la Cordillera Andina que define claramente tres zona ecológicas; los cerros muestran laderas suaves y marcados declives, y aunque distantes los ríos, las tierras en general son fértiles con agua de subsuelo y formas de vida silvestre en los bosques.

Múltiples caminos de herradura cruzan el territorio en todas las direcciones. Un camino carretero la enlaza con otros distritos de la provincia y permite la salida de sus productos a la ciudad de Chiclayo.

De la densidad y el área que ocupan los materiales culturales, se puede inferir que los habitantes más antiguos de Pacopampa se establecieron en forma permanente en una amplia extensión, con unidades dispersas para el aprovechamiento de la variada ecología. Pueblo cuya economía debió ser básicamente agrícola, pero donde la caza ejerció rol importante, como lo evidencian los numerosos restos óseos de camélidos, cérvi- 
dos (Odocoileus peruvianus), cuyes (Cavia sp.), entre otros.

En la Fase Pacopampa no hemos encontrado manos de moler, metates, ni ningún artefacto que pudiera ser empleado para la caza, debido probablemente a que nuestros trabajos estuvieron concentrados en el área ceremonial y no en lugares de vivienda; además, en el caso de los instrumentos de molienda, es posible que la sugerencia dada por Reichel-Dolmatoff para Momil I funcione aquí y que la ausencia se deba a la existencia de una agricultura de raíces, hasta hace poco muy practicada por los pobladores. Entre los cultivos se destaca la rakacha, no solo por sus propiedades alimenticias y conservativas (se la puede guardar hasta dos años en buenas condiciones), sino por la preferencia que se le concede y la propiedad que tiene para crecer sin exigir cuidados especiales, inclusive en terrenos de baja calidad, malos para otros sembríos. Hemos contado hasta 9 variedades de rakachas que denotarían, tal vez, la atención que debió merecer en el pasado.

La presencia de elementos chavinoides, sin embargo, está asociada a estos instrumentos agrícolas. Es probable que plantas como el maíz, frijol y quizá calabaza, de cultivo asociado en el presente, pueden datar de esa fecha.

Los restos arqueológicos de plantas alimenticias, difíciles de encontrar en medios arcillososhúmedos como el de Pacopampa, limitan nuestro conocimiento.

En la Fase Pacopampa, la uniformidad técnica y estilística de la cerámica señala existencia de una fase cultural con probable diferencia temporal, expresada en el espesor de la acumulación. En los inicios de la fase, el contenido cultural sin ser escaso es menor en comparación con la porción media, donde aumenta notoriamente.

En cerámica le caracteriza: incisiones cortantes o superficiales, pintura roja post-cocción en áreas, la aplicación de tiras y pastillas, pinturas pre-cocción en rojo, ante y blanco en zonas, exciso, peinado; engobe rojo, motivos en general geo- métricos, bandas escalonadas, meandros, etc. Corresponde también a esta cultura una arquitectura de mampostería ordinaria, material canteado, forma irregular, con barro y pachilla como argamasa; tipos todos que declinan, mientras otros aparecen y siguen su propio curso de desarrollo.

La Fase Pacopampa-Chavín, segregada de la anterior por el contexto estratigráfico y su tipología cultural. La presencia de la cultura chavinoide está asociada a nuevas técnicas en la fabricación cerámica, esculturas líticas, estilo arquitectónico, tallas en hueso y ritos funerarios.

Caracteriza a esta fase: la incisión pulida y regular, decoración bruñida, pintura rojas postcocción y raros grafitados, círculos estampados en variadas combinaciones, diseños de serpientes y felinos; el empleo de piedras talladas con artistas y aparejo uniforme, colocadas en forma simétrica o alternadas en posición verticalhorizontal, asociadas a columnas cilíndricas; la representación de figuras antropomorfas en piedra o hueso; la talla de morteros escultóricos de tamaño diverso, estelas con distintas representaciones y variados monolitos.

Practicaron entierros con ofrendas y ritos, como lo indican los cadáveres pintados de color rojo y trozos de cristal de roca en la boca, acompañados de platos o tazas de barro, muy bien pulidos y decorados. Si la fase Pacopampa-Chavín implica la aparición de nuevos patrones, hay elementos tradicionales que continúan, por el momento sólo perceptibles en las formas y motivos decorativos de la cerámica; se siguen diseñando las figuras felínicas, la aplicación de pigmento rojo y se fabrican bols y platos de labios redondos, biselados, dentados, almenados y lobulados.

Los tipos acordonado y modelado-cintado, que aparecen estratigráficamente después de Pacopampa, se relacionan en estilo a la Fase Pacopampa-Chavín. Sin embargo difieren de ella pues son eminentemente figurativos, con representaciones antropomorfas, frecuente uso de col- 
millos, pupila excéntrica, manufacturadas con la técnica modelada y la aplicación de cintas de arcilla, adoptando la forma de grandes vasijas. Asimismo sucede con los tipos ojo inciso fino y bandas rojas, que tienen posición más tardía en la secuencia y se relacionan con tipos similares de Machalilla en la costa ecuatoriana.

\section{Posibles relaciones culturales}

La revisión bibliográfica sobre el Período Formativo nos ha permitido señalar algunas semejanzas o diferencias estilísticas y tipológicas de los materiales de Pacopampa y otros complejos formativos conocidos, que parecen sugerir la existencia de una antigua tradición común, pero a la vez desarrollo en medios ecológicos distintos y relaciones interculturales en época posterior.

En Pacopampa, una larga secuencia cultural Pacopampa-Cajamarca pone de manifiesto el transcurso de un gran espacio de tiempo durante el cual se dieron una serie de contactos con culturas alejadas o cercanas, al mismo o en diferente período de tiempo y en grado también diverso.

Su ubicación geográfica facilitaría la comunicación entre las culturas del norte, de Ecuador y Colombia, principalmente a través del Marañón y sus afluentes, y las de la Costa y Sierra Andina, al Sur.

En la Sierra Norte debemos señalar a Kunturwasi, sitio ceremonial a $2 \mathrm{~km}$ del pueblo de San Pablo, al sur del departamento de Cajamarca, dado a conocer por Rebeca Carrión Cachot en su artículo Cultura Chavín, en base a trabajos de excavación efectuados por personal del Museo Nacional de Antropología de Lima en el año 1946.

El material descrito por la autora se identifica con los tipos Acordonado y Cintado de Pacopampa-Chavín (Lám. XXIII, 15-32). Son también comunes, las figuras con boca de terminación romboidal, ojo de pupila excéntrica enmarcado por una banda que termina en sus extremos verticales en una voluta, orejera circular y cabecita de serpiente en el extremo superior de la oreja (monolito de la p.152, 16), las formas de bols, platos, ollas, cántaros de cuello corto, bordes almenados y bases anulares.

La cerámica mencionada e ilustrada por Carrión, escasa y seleccionada, se relaciona únicamente con la Fase Pacopampa-Chavín. Sin embargo, el material que está siendo revisado por Toribio Mejía Xesspe, parece denotar vinculaciones con la Fase Pacopampa.

Al sur de la zona, en el departamento de Áncash, Chavín de Huántar muestra algunas similitudes con la Fase Pacopampa-Chavín. Basándonos en un reciente informe (Lumbreras y Amat, 1969), encontramos que ambos sitios participaron en el empleo de engobe rojo, incisiones pulidas, pintas de grafito, decoración interna y externa, con motivos de serpientes, aves o simplemente geométrico, del tipo Rocas grafitado (p.174, Lám. I).

Igualmente el tratamiento de la superficie, forma decoración a base de círculos estampados simples o dobles, y el empleo de pintura roja post-cocción de los tipos Rocas Gris pulido y Negro fina (Lám. II y IV, pp. 174, 75). Sin embargo, en Pacopampa no aparecen los motivos imbricado-peinado y es muy raro el mecido; ni en Chavín los bordes lobulados, almenados y dentados o la cerámica modelada y aplicada, la diversidad de decoración bruñida y las incisiones finas con motivos sombreados.

Son también similares los patrones arquitectónicos de barro y pachilla como argamasa, la alternancia de piedras altas y bajas (verticalhorizontal), muchas pulidas de aristas regulares y tamaño uniforme, escalinatas de acceso, galerías, columnas y estelas pero en Chavín de Huántar, mucho más elaboradas.

Bajando hacia la costa, encontramos las fases Negritos y Paita A, B. (Lenning, 1963) en el área Piura-Chira, con las que Pacopampa comparte formas y decoración, jarras de cuello corto y alto, borde evertido, expandido o reforzado exteriormente (fig. 1, b, c; 21 a-b), bols de borde expandido, labios dentados; aplicación de tiras de arci- 
lla o botones, incisiones cortantes sobre superficie externa tosca sin pulir, diseños geométricos (figs. 21, i, o-p, u, x, z). Sin embargo, en Pacopampa se observa mayor variedad decorativa, diseños figurativos, además de otras técnicas como la pintura precocción en áreas hasta de tres colores y la frecuencia de engobe rojo (Rosas-Shady, 1970)

Menos rasgos tiene en común con el complejo cerámico temprano de Guañape, ubicado más al sur, en el valle Virú, tales como la aplicación de tiras impresas con los dedos e incisos (figs. 45, 46 de la publicación de Stronge Evans, 1952), protuberancias circulares con puntuaciones centrales (fig. 47, d, f) y modelado de figuras principalmente de animales (fig. 47, e, f), elementos todos que si bien aparecen desde temprano, son poco frecuentes en Pacopampa. El punteado en zonas, algo tardío en Guañape, también se da en Pacopampa, pero escaso asociado al inciso cortante. Comparten las jarras de cuello corto, cuerpo globular y base redondeada, los bols de lados curvos o rectos, base convexa o aplanada (figs. 352-4), pero las jarras grandes de boca constreñida y base cónica, forma típica de Guañape no ha sido encontrada en Pacopampa.

Alejándonos de esta zona, hacia el sur, en la Costa Central, nos distanciamos también culturalmente. No encontramos evidencias de relación entre la Fase Pacopampa y las fases Chira, La Florida y Calvario, del Período Inicial en Ancón (Rosas, 1970). Indudablemente este pueblo de pescadores y colectores de mariscos tenía patrones culturales diferentes a los de Pacopampa durante la parte temprana del Formativo. Las relaciones culturales son más estrechas con la Fase Pacopampa-Chavín, tanto en la forma de las vasijas como en la decoración; bols de hombro ligeramente angular, círculos estampados en el área externa inmediata a los bordes o cubriendo la superficie; color gris y marrón oscuro, esmerado pulido, representación del felino, empleo de color rojo en las incisiones y pintura bicroma, constituyen los elementos más caracterizados que con leves modificaciones comparten también Kotosh, el mismo Chavín de Huántar y otros sitios más. Sin embargo, rasgos como el mecido, poco frecuente en Pacopampa, y la presencia en ésta de rasgos tales como la decoración bruñida, las vasijas moldeadas y aplicadas con diseños básicamente figurativos, cerámica incisa fina con motivos sombreados, los bols de labios almenados, lobulados y dentados, marcan la separación con probable significado temporal.

Siguiendo por la costa, en dirección Sur, en los valles de Ica y Pisco, ha sido identificada, primero por Tello, la cerámica de ParacasCavernas, y posteriormente por Menzel, Rowe y Dawson (1964) Ocucaje. En este último trabajo, establecen los autores 10 fases que se inician con la influencia Chavín. A pesar que en Pacopampa la cerámica de esta fase antecede a Chavín, propiamente dicho, que sugiere por tanto una separación temporal entre Pacopampa y Ocucaje, culturalmente, no obstante la distancia geográfica, las vinculaciones expresadas en la cerámica son muy estrechas. Se asemejan la técnica de tratamiento y color de superficie, bols de contorno redondeado, base convexa, incisiones cortantes, diseños a base de bandas, escalones y la pintura post-cocción en áreas. Estos rasgos también los observamos en piezas procedentes de Huanta, Ayacucho. La presencia de pintura negativa, vasijas de doble pico y asa puente, mayor variedad de formas, colorido y complejidad de los diseños de Ocucaje, serían las principales diferencias entre estas dos culturas. Sin embargo, los elementos básicos que tienen en común denotan que ambos complejos se expresan en el mismo lenguaje artístico y es probable que pertenecieran al mismo grupo cultural, diversificado Ocucaje por el tiempo y los contactos con culturas de otras áreas.

Más sorprendente aún es la relación que observamos entre la cerámica pintada precocción, en zonas rojo o ante, blanco y gris, delimitadas por incisiones de Pacopampa (Típica de Bagua en el valle del Utcubamba), con la alfare- 
ría de la Cuenca Norte del Lago Titicaca (Kidder II, 1943). A juzgar por los datos presentes (ausencia de evidencias en la Costa y Sierra Central), la vinculación de Pacopampa con esta zona y los valles de Pisco e Ica, debió darse a través de los flancos orientales de la cordillera.

Fuera del área de los Andes Centrales, los elementos de comparación con complejos cerámicos temprano son muy reducidos como para sugerir relaciones o derivaciones culturales de alguno de ellos. Más bien pensamos que de ser cierta la difusión de Norte a Sur, al centro de donde se dispersó, podría estar en los valles interandinos, al norte de la sierra peruana, en Ecuador o más probablemente Colombia.

\section{BIBLIOGRAFIA}

BENNET, Wendell C.

1936 Excavations in Bolivia American Museum of Natural History, Anthropological Papers. Vol. 35, pt.4, pp. 329-507. New York.

1946 "The Archeology of the Central Andes". En, Handbook of South American Indians. Bureau of American Ethnology. Bulletin 143, vol. 2, pp. 61-147. Washington, D.C.

CARRIÓN CACHOT, Rebeca

1948 "La cultura Chavín: Dos nuevas colonias: Kuntur Wassi y Ancón”. En: Revista del Museo Nacional de Antropología y Arqueología, vol. 2, N 1, pp. 99-172, Lima.

IZUNI, Seiichi y SONO, Toshihiko

1963 Andes 2: Excavations at Kotosh, Perú, 1960. Kadokawa Publishing Co. Tokyo.

KIDDER, Alfred II

1943 "Some Early Sies in the Northern Lake Titicaca Bason". En: Papers, Peabody Mueum, Harvard University. Vol. 27, $\mathrm{N}^{\circ} 1$.

LANNIN, Edward

1963 "A Ceramic Sequence for the Piura ande Chira coast, North Peru". University of Califormia Publications in American Archaeology an Ethnology. Vol. 46, N², pp. 135-284. Berkeley, California.
LARCO HOYLE, Rafael

1941 Los Cupisniques. Casa Editora "La Crónica y Variedades". Lima.

1946 "A Cultural Sequence for the north coast of Peru". En, Handbook of South American Indians. Bureau of American Ethnology. Bulletin $\mathrm{N}^{\circ}$ 143, Vol. 2, pp. 149-175. Washington, D.C.

LUMBRERAS, Luis y AMAT, Hernán

1969 "Informe preliminar sobre las galerías interiores de Chavín". En: Revista del Museo Nacional. Tomo XXXIV, pp. 143-195. Lima.

MEGGERS, Betty; EVANS, Clifford y ESTRADA, Emilio

1965 Early Formative Period of Coastal Ecuador: The Valdivia and Machalilla Phases. Smithsonian Contributions to Anthropology. Vol. I, Washington, D.C.

MENZEL, Dorothy; ROWE, Jhon y DAWSON,

Lawrence

1964 The Paracas pottery of Ica, a study in style and time. University of California. Publications in American Archaeology and Ethnology. Vol. 50.

REICHLEN, Henry y Paule

1949 "Rechecher archeologiques dans les Andes de Cajamarca: Premier Rapport de la Mision Etnologique Français au Pérou septentrional". En, Journal de la Societpe des Americanistes de París. Vol. 38, pp. 137-174.

ROSAS LA NOIRE, Hermilio

1970 "La secuencia cultural del Período Formativo en Ancón". Tesis de grado en el Programa Académico de Psicología y Ciencias Sociales. Universidad Nacional Mayor de San Marcos. Lima

ROSAS LA NOIRE, Hermilio y SHADY SOLÍS, Ruth

1970 "Pacopampa: Un complejo temprano del Período Formativo Peruano". (Trabajo presentado al XXXIX Congreso Internacional de Americanistas, Lima 2-9 agosto de 1970); impreso por "Seminario de Historia Rural Andina de la UNMSM. 
SHADY SOLÍS, Ruth y ROSAS LANOIRE, Hermilio

1970 "Informe preliminar de las exploraciones arqueológicas en la Cuenca del Marañón". Trabajo presentado al XXXIX Congreso Internacional de Americanistas, Lima, agosto , 2-9 de 1970; impreso por el "Proyecto Andino de Estudios Arqueológicos", Lima.

STRONG, William y EVANS, Clifford

1952 Cultural Stratigraphy in the Viru Valley, Northern Peru: The Formative and Florescent epochs. Columbia University Press. New York.
TELLO, Julio C.

1956 Arqueología del Valle de Casma. Universidad Nacional Mayor de San Marcos, Lima.

1960 Chavín. Cultura matriz de la civilización andina. Universidad Nacional Mayor de San Marcos. Lima.

TOSI, Joseph

1960 "Zonas de vida natural en el Perú". Instituto Interamericano de Ciencias Agrícolas de la OEA, Zona Andina. Boletín Técnico $\mathrm{N}^{\circ} 5$. 